\title{
The supply of the public lacus of Pompeii, estimated from the discharge of their overflow channels
}

\author{
Maria C. Monteleone ${ }^{1}$ D $\cdot$ Martin Crapper $^{1} \cdot$ Davide Motta $^{1}$
}

Received: 5 January 2020 / Accepted: 3 June 2021 / Published online: 30 June 2021

(c) The Author(s) 2021

\begin{abstract}
The term lacus generally identified the public fountains in the main streets of ancient Roman towns, providing for the population daily water demand. The simplest lacus consisted of a stone basin and a spout stone, concealing one or two supply pipes. 35 street fountains of this type have been surveyed in Pompeii, to gather information on their supply and its variation in time. A new method was devised for calculating the discharge through the overflow channel of each lacus, and this value was taken as an estimate of the water supplied to each fountain. The overflow channel internal cross-section width was measured at four elevations, and the cross-section profile was reconstructed based on these data. Three water levels of $1 \mathrm{~cm}$, half of the cross-section height and entire cross section height, were considered at each channel's inlet, obtaining a corresponding channel discharge. The values obtained, ranging from 0.03 to $2.9 \mathrm{l} / \mathrm{s}$, were checked against the trajectory of the fountain water jet, making sure that it remained within the basin length. For 28 fountains the average discharge was found to be $0.08 \mathrm{l} / \mathrm{s}$ when the water was at the lowest level, $0.43 \mathrm{l} / \mathrm{s}$ for the intermediate level and $1.18 \mathrm{l} / \mathrm{s}$ for a full inlet. The average time of residence of the water, in the lacus draw basin, was estimated between 11 min and $3 \mathrm{~h}$. An estimate of the demand of all the town lacus was compared with the capacity of the aqueduct channel entering at Porta Vesuvio: the town lacus could have been supplied contemporaneously at the minimum and intermediate discharges.
\end{abstract}

Keywords Ancient Roman fountains · Pompeii · Roman water supply $\cdot$ Lacus

Maria C. Monteleone

maria.monteleone@northumbria.ac.uk

Martin Crapper

martin.crapper@northumbria.ac.uk

Davide Motta

davide.motta@northumbria.ac.uk

1 Department of Mechanical and Construction Engineering, Northumbria University, Ellison Place, Newcastle upon Tyne NE1 8ST, UK 


\section{Introduction}

The street fountains in ancient Roman towns provided for the majority of the population daily water demand, being the private houses connected to the public mains, limited in number. The typical and simplest type of lacus was defined by Agusta-Boularot (2008b, p. 95): a quadrangular basin made of stone slabs, flanked by an upright stone block housing a lead supply pipe that discharged water through a decorative mask. The water was stored in the basin and continuously or very often replenished. Water containers could be filled either under the water jet or by immersion; excess water spilled through an overflow which, for the Pompeian fountains and many similar examples, consisted in a small channel carved in the top rim of the basin (Fig. 1).

This type of fountain was built from the Republican age in various towns in Italy, such as Paestum and Aletrium (Agusta-Boularot 1997) and, starting from the Augustan age, in the Roman towns of the western provinces (Agusta-Boularot 2008a; Schmölder-Veit 2009). Some examples are shown Fig. 2. In Pompeii 42 public fountains have been described by Eschebach and Schafer (1983) in their catalogue; 35 of them present the layout of the simple lacus described above.

\section{Objectives of the study}

Published studies on the Roman lacus fountains have focused on their architectural and decorative features rather than their hydraulic features. Only recently the role of fountains in the entire network operation was reconsidered (Richard 2012). Therefore, there are many aspects of fountain design and operation that have yet to be understood. In this regard, Pompeii presents to its visitors an almost complete water distribution system of the Augustan to early Imperial age. Although many uncertainties remain on the dating of the various water structures, ${ }^{1}$ for the purpose of this study, we make the assumption that the visible fountains were all included in the water distribution network, at least for various years, before the destruction of the town.

The flowrate supplied to ancient fountains has been estimated for a limited number of isolated structures. Vannesse et al. (2014) calculated, for three private installations fed by rear-placed reservoirs in byzantine Apamea, ${ }^{2}$ a flowrate in the range 7 to $33 \mathrm{l} / \mathrm{s}$. Ortoloff and Crouch (2001) calculated a maximum flowrate of $3.8 \mathrm{l} / \mathrm{s}$ for each of the ten spouts of the Ephesus fountain house. Fahlbusch (2006) estimated a flowrate of 1.0 1/s for an Hellenistic fountain fed by a terracotta pipe in Priene and 0.75-3.0 1/s for a public fountain consisting of an upright stone for the pressure pipe and a front slab base holding the containers at the front. The last two examples of fountains are similar in their hydraulic arrangements and size to the Pompeian fountains. Both Vannesse and Fahlbusch calculated the maximum fountain discharge, based on the trajectory of the water jet, confined within a specified distance from the spout. A similar method was applied to 15 Pompeian fountains (Monteleone 2009), obtaining flowrates between 3 and 6.6 1/s, for the water jet reaching the far end of the basin.

\footnotetext{
1 For the discussion on the evolution of the water system in Pompeii see Eschebach (1996), Ohlig (2001, pp. 72-78), Jansen (2002) and Keenan-Jones (2015).

2 The fountains consisted of a front basin fed by a back reservoir through a pipe; the basins size ranged from 1 to $7 \mathrm{~m}^{3}$. The reservoirs were supplied both by rainwater and the public aqueduct.
} 
In this paper a different method is explored, based on the calculation of the discharge of the fountain overflow channels, under the assumption that the discharge was related to the supply of the fountain ${ }^{3}$ (Kessener 2013). The main input data of our calculations are the diameter of the spout orifices and the size and shape of the overflow channels. The outputs obtained are the basin discharge, the trajectory of the water jets at the spouts and the hydraulic retention time of the basins. A range for the total discharge of 39 Pompeii lacus is estimated in litres/second and in quinariae, to be compared with the figures reported by Frontinus for Rome (Rodgers 2004) and with the water discharged by the aqueduct channel in the castellum divisorium at Porta Vesuvio.

\section{The survey data}

The geometric data on fountain spouts and overflow channels was acquired during four field survey visits, conducted between 2017 and 2019. The fountains were observed in their present condition and the measurement were taken of the visible elements. Several fountains were reused in modern times, through the insertion of a tap in the original spout: in one case the dimensions of the spout were not identified, in other three cases the spout stone was missing or replaced by a modern one. ${ }^{4}$ The overflow channels, which are at the base of this study, were not altered in modern times. We found that three fountains' basin volume was reduced from the original size in ancient times, possibly as a consequence of a reduced supply; this possibly allowed to maintain unaltered the residence time of the water in the basin, as explained later in this paper.

The data on the fountains included in Notizie degli Scavi, reporting on excavations over various years, was very limited. ${ }^{5}$ Eschebach and Schafer (1983) included in their catalogue 42 public street fountains in Pompeii, giving details of their general layout and describing the spout stone relief. Out of the 42 fountains in the catalogue, the 35 presenting the layout of a lacus are the object of our study. Figure 3 identifies the 33 lacus surveyed with yellow boxes. The yellow, semi-transparent boxes identify Fountains 19 and 10, which were not accessible at the time of our survey. The white boxes identify the seven fountains with a layout different from a lacus. ${ }^{6}$

\footnotetext{
${ }^{3}$ Kessener (2013) identified the possibility of estimating Pompeii lacus supply from the calculation of the overflow channels discharge and to compare the quinariae supplied to Pompeii lacus with the figures for Rome, finally estimating a value for the quinaria unit discharge: "Water was taken from the lacus mainly during daytime, at night they invariably filled up as the water flow never stopped. Surplus water flowed from the basins through an overflow in the rim, flowing to the street and thence the drains. The outflow through these overflows of course matched the inflow. From data of basins that have survived the discharge through the overflows may be determined. This may give a clue of how much water the lacus generally received, and, as the lacus at Rome took, within rather narrow limits, 2.26 quinariae, an idea, based on archaeological material, of how much 1./sec one quinaria may have been".

${ }^{4}$ See Table 2. Fountain 31 spout orifice dimensions were not easily identified, Fountains 9, 17 and 23 had the spout stone missing or replaced by a modern one.

${ }^{5}$ For example in 'Notizie degli Scavi' of year 1906, the description of Fountains 19 and 20 consisted of a couple of lines, mentioning the general layout of the fountains; similarly Notizie degli Scavi of year 1879 reports only one line of text, mentioning the finding of Fountain 40.

${ }^{6}$ Fountains 15 and 36 were not lacus and also there are not sufficiently visible remains. Fountain 25 is located within a niche on the north side of the Germanicus arch, north of the forum, fed by an upper reservoir (a second reservoir is found within the other base of the arch). Fountains 11, 30 and 38 present the spout stone carrying the supply pipe, but not the collection basin (see note 13 for hypotheses on their operation).
} 
Fig. 1 The simplest type of lacus (Fountain 34 in Pompeii), showing the elements surveyed in our study

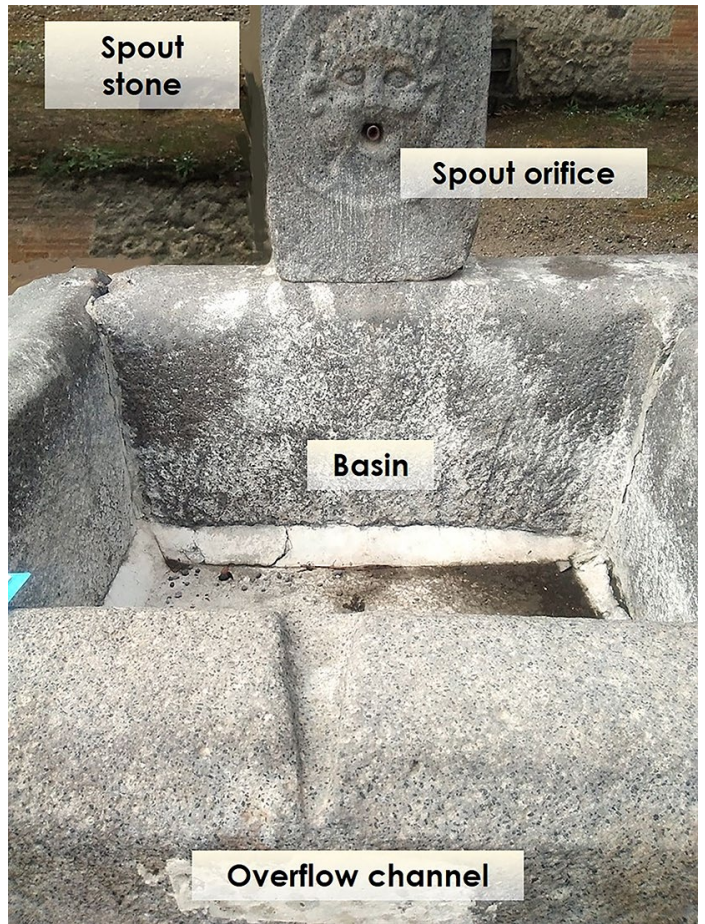

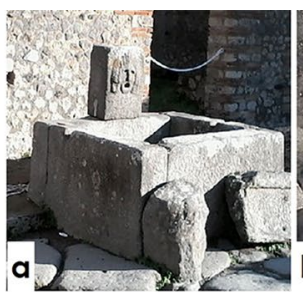
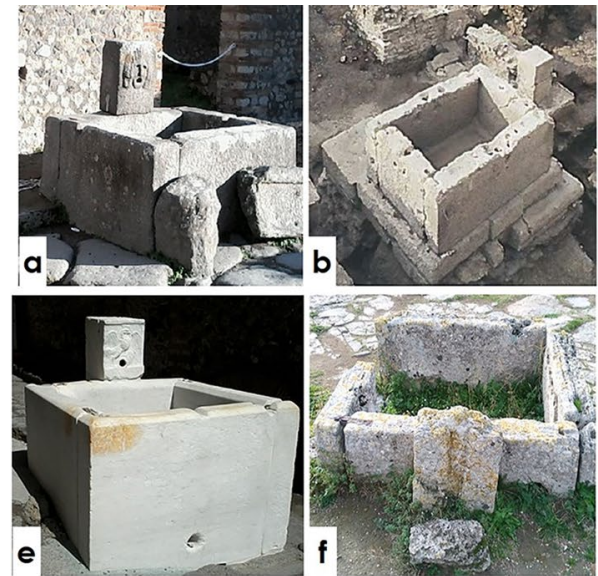
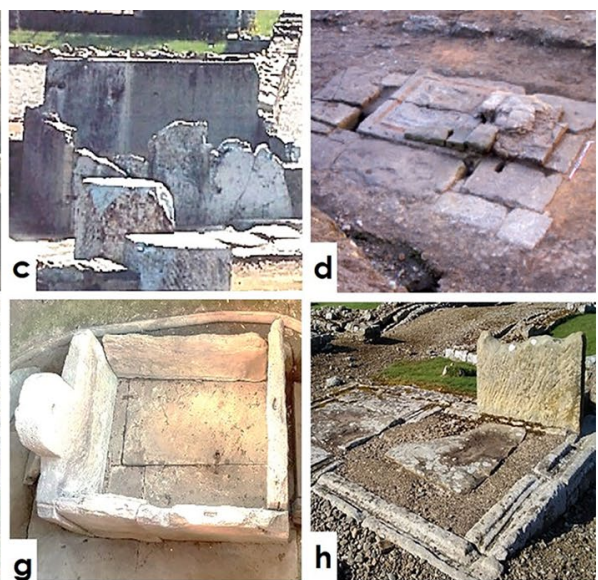

Fig. 2 Examples of lacus fountains in the western provinces: a Italy, Pompeii, b France, Lyon, (Delaval and Savay-Guerraz 2004, p. 71), c France, Saint Romain en Gal (Brissaud 2004, p. 107), d France, Poitiers (Gerber and Bambagioni 2009, Fig. 19), e Italy, Pompeii, f Italy, Paestum, g Italy, Aqui Terme, Corso Roma, h England, Corbridge Roman fort

The dimensions of the fountains' basin and a description of the layout of the basins was given by Nishida (1990). Nappo (2002) provided information on some stretches of the fountains' supply pipes, found in deep trenches along the footpaths. 


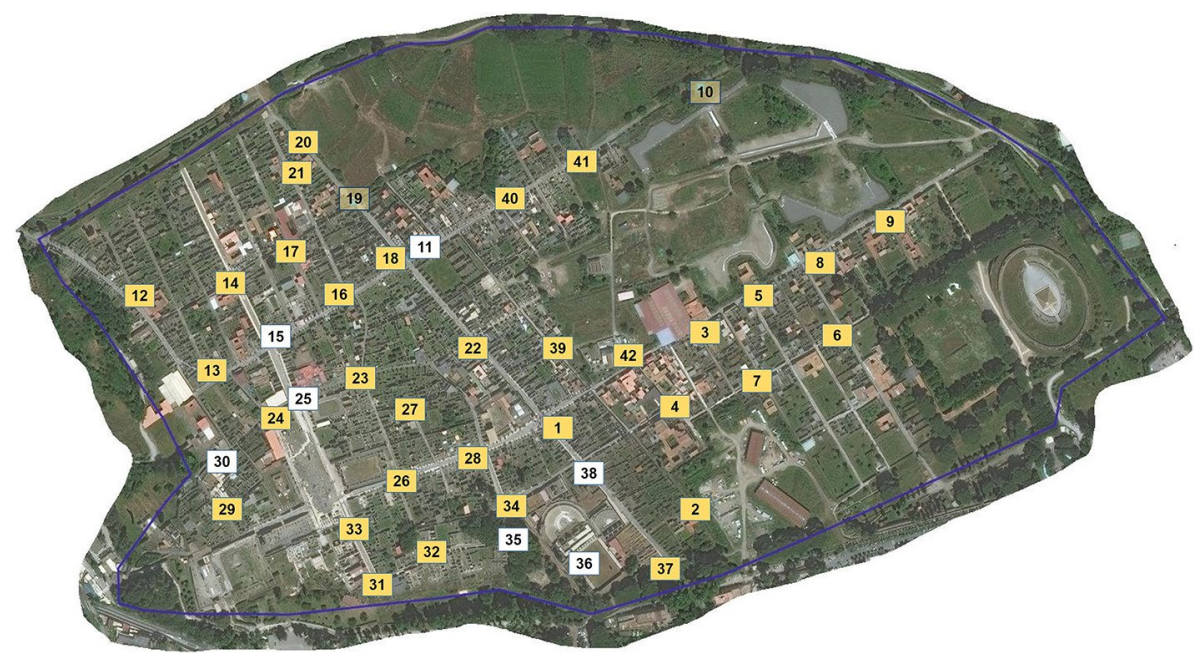

Fig. 3 Aerial view of the archaeological site of Pompeii showing the location of the 33 lacus fountains (yellow boxes), two lacus fountains not surveyed (yellow, semi-transparent) and seven non-lacus fountains, excluded from our analysis (white boxes)

The features of the fountains recorded during our survey were the maximum and minimum diameter of the spout orifice, the size and shape of the overflow channels and the height of the spout orifice over the top edge of the basin.

\section{Recording the overflow channel features and cross-section}

The overflow channel was an essential feature of the lacus fountains, directing the excess water onto the public road. People accessed the fountains from the pavement side only, especially in the roads open to wheeled traffic. In Pompeii the most frequent orientation of the fountain is with the spout stone located over the footpath, ${ }^{7}$ the signs of wear showing at the side of the spout stone (Fig. 4). The overflow channel is often ${ }^{8}$ on the opposite side, its position depending on the slope of the road surface. ${ }^{9}$

We do not have enough information on the dating of the single fountains; some overflow channels present very worn top edges, while other channels are so well preserved that they appear hardly used. The amount of wear is also dependent on the stone materials used for the basin (Fig. 5h and i). We could not find significant calcium carbonate deposits marking the level of the water either in the basin or on the area wetted by the overflowing water, below the channel outlet. ${ }^{10}$

\footnotetext{
7 This is attested by the high wear of the top side of the basin stone on either side of the spout. Fountains 17, 19 29, 32 and 39 have the spout stone perpendicular to the footpath; in these cases, the signs of wear are on the footpath side.

820 out of 33 fountains have the overflow channel at centre front position, opposite the spout stone.

9 On the paving, slope and drainage of Pompeii roads, see Poehler (2017).

10 Only in Fountain 14 were some deposits below the channel outlet visible; in the other cases possibly the water jet had enough velocity to remain detached from the basin side? It must be noted that some fountains were put back in use and subject to regular cleaning, in which the original sinter marks may have been lost; some deposits would have formed during the modern use of some fountains. The chemical analysis of the
} 
In two cases (Fountain 40 on the Via di Nola and Fountain 18 on Via Stabiana) the lower surface of the overflow channel at its end is extended for a few centimetres clear of the stone side of the lacus $^{11}$ (Fig. 5e). Two fountains, 24 (Fig. 5a) and 27, have more than one overflow channel. ${ }^{12}$ Fountain 6 , in tufa, does not have a proper channel, but the visible gap between the two front left elements seems to have been shaped to function as an outlet (Fig. 5d). Fountain 31, the only one with a brickwork basin (Fig. 5b), lacks a proper overflow, the basin possibly being added at a later date. ${ }^{13}$ Fountain 32 presents an orifice immediately below the overflow channel, with its axis $12 \mathrm{~cm}$ lower than the weir channel bottom (Fig. 5c) whose function is discussed later. Typically, each overflow channel starts with a wider entrance cross-section, shaped to favour a smooth water transit, followed by a stretch with a constant cross-section, slightly sloping up away from the fountain basin. Some channels slightly taper off towards the outlet section (Fountains 2, 3 4, 7, 9, 12 and 18); in only three cases (Fountains 23, 26 and 34), the two sides are significantly convergent (Fig. 5h).

Table 1 gives the measure of the top width, the height and cross-section area of the channels' inlet cross-section. The size and shape widely vary across the fountains. Parabolic, rectangular (Fig. 5f) and trapezoidal cross-sections (Fig. 5g) are found, with a prevalence of the latter. For the trapezoidal type the average measure of the top width is $8.9 \mathrm{~cm}$, the bottom average width is $4.3 \mathrm{~cm}$ and the average height is $5.4 \mathrm{~cm}$.

The overflow channel length, equal to the slab thickness, varies between 18 and $34 \mathrm{~cm}$ with an average of $28 \mathrm{~cm}$. Based on these measurements, the channels can be identified, for the purpose of discharge calculation, as broad crested weirs. The condition that the length is greater than two times the maximum water level $(3.5-9 \mathrm{~cm})$ at the inlet section is verified for all the overflow channels. The critical water depth occurs in a section within the channel length, so that supercritical flow is established at the outlet. This, in turn, implies that the channel discharge is only determined by the geometry and water height at the inlet cross-section, and not at the outlet cross-section. It was therefore sufficient to record data only for the inlet cross-section in the survey.

The overflow channel width was measured at three different levels from the bottom $(0,2$ and $4 \mathrm{~cm})$ as well as at the channel maximum height. Starting from these measurements, the section profile was reconstructed by interpolation. This method is illustrated for

\footnotetext{
Footnote 10 (continued)

sinter deposits was not included in this study; it could be useful for the comparison with the deposits found in other structures such as in Matsui et al. (2009).

$114 \mathrm{~cm}$ for Fountain 40 and $1 \mathrm{~cm}$ for Fountain 18.

12 Fountain 24 has three overflow channels and Fountain 27 has two.

13 The rim of the fountain basin is depressed at the front, for a depth of $5.4 \mathrm{~cm}$ and a width of about $44 \mathrm{~cm}$. The discharge would have been over $7 \mathrm{l} / \mathrm{s}$ if the depression functioned as an overflow channel. Since this fountain is significantly different from the others, it was not included in the discharge analysis. The spout stone for this fountain is a monolithic piece, extending down to the basin base. In this regard Fountain 31 is similar to Fountains 11, 30 and 38, presenting a vertical stone, concealing the pipe, and no collection basin. One explanation for these fountains is that they returned to the public road, for the public use, the unused water from nearby premises. Therefore, their supply could have been more discontinuous and reduced in quantity than the average lacus supply. The retention time would probably have been longer than $4 \mathrm{~h}$ if a collection basin was present. Dessales (2011) also favoured the hypothesis that this type of fountains (identified as 'bornes-fontaines') delivered the 'aqua caduca' or unused water, for the benefit of the industrial workshops nearby. Our suggestion is that Fountain 31 could have been originally a 'borne-fontaine', the brickwork basin being added at a later time, when an increased supply assured the appropriate retention time of the water.
} 

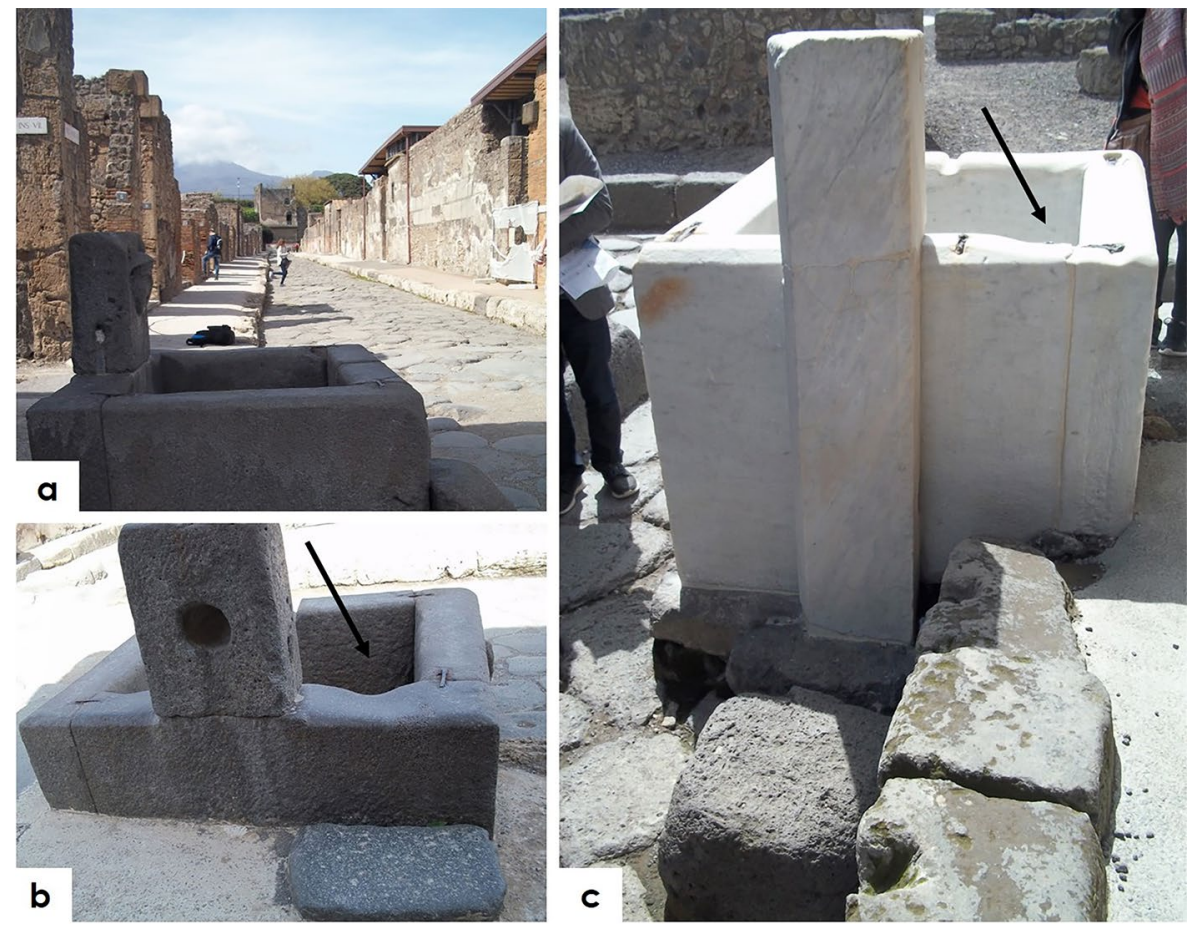

Fig. 4 a Example of the most common orientation of the fountains in Pompeii, with the spout stone on the side of the footpath and the overflow channel in front, $\mathbf{b}$ signs of wear near the spout stone due to the basin being accessed from the footpath, $\mathbf{c}$ example of a fountain with the stone spout located perpendicularly to the footpath, showing signs of wear on the footpath side

Fountains 14 and 37 in Fig. 6. In the same figure the discharge curve, obtained as explained in the following paragraphs, is shown.

\section{Spout orifices and original pipes' size}

The original lead pipes supplying the lacus fountains have never been found within the spout back stone and orifice, during modern surveys. Nappo (2002) described pipes found below the footpaths, heading in the direction of some of the fountains; they were cut off at various distances before the basins. We can get an indication of the diameter of the supply pipes from the vertical grooves at the back of the spout stone and from the size of the spout orifice. The only supply pipe remaining visible in Pompeii is behind the basin of Fountain 27 in Vico della Maschera, cut off just above the footpath level (Fig. 7a and b). The ongoing excavations in Regio V have revealed, in the year 2019, a lacus fountain with the original supply pipe in place (Fig. 7c and d); unfortunately we have not been able to inspect the fountain or access information on its size and construction details.

We found for Fountain 27 spout orifice a maximum and minimum diameter of 4.9 and $3.5 \mathrm{~cm}$; for the lead pipe at the back a maximum and minimum external diameter of 5.4 

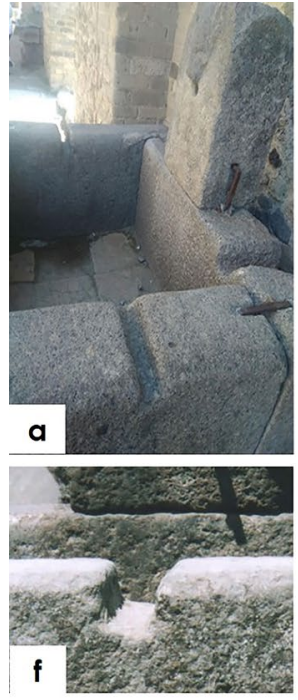
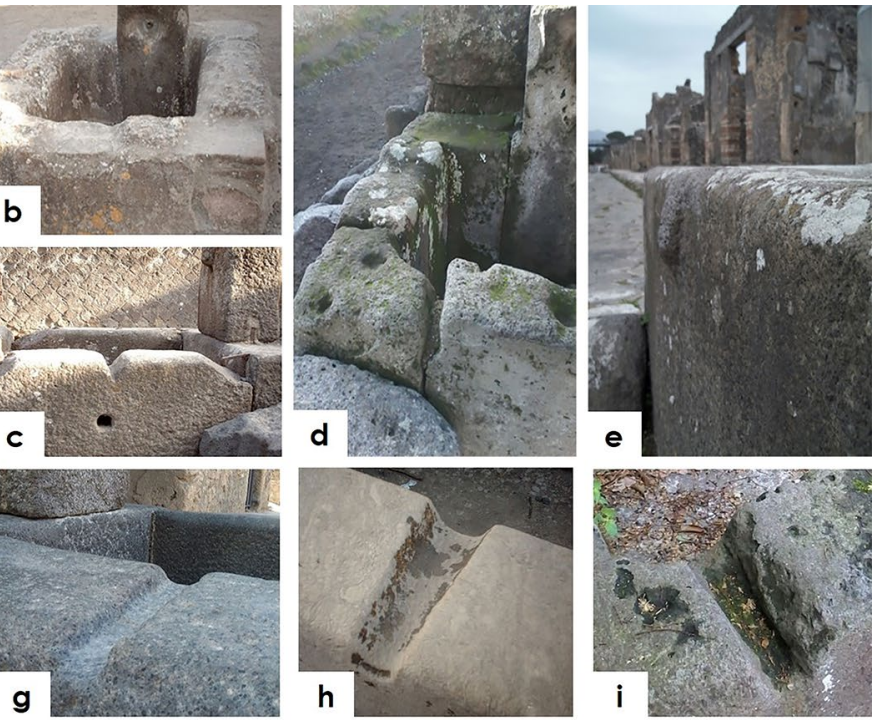

Fig. 5 Distinctive features of some overflow channels: a Fountain 24, with three overflow weirs; b Fountain 31 , with a masonry basin presenting a large lowered front area; c Fountain 32 with an orifice lower than the original weir; d Fountain 37, with a gap between the two slabs at the front left in place of the regular channel; e Fountain 40, whose channel bottom is prolonged for $4 \mathrm{~cm}$ out from the side of the lacus, f Fountain 13 overflow channel, with the largest rectangular cross-section; g Fountain 4 overflow channel, with a trapezoidal cross-section of minimum height; h Fountain 26 overflow channel, with neat edges (basin in travertine) and sides converging towards the outlet; i Fountain 37 overflow channel, with worn edges (basin in tufa)

and $3.4 \mathrm{~cm}$, a maximum and minimum internal diameter of 3.2 and $2.1 \mathrm{~cm}$. The pipe thickness varied between 4.7 and $5.3 \mathrm{~mm} .{ }^{14}$

A close visual inspection inside the spout orifices for all fountains showed some small lead fragments (with dimensions less than $1 \mathrm{~cm} \times 2 \mathrm{~cm}$ ), firmly attached to the stone (Fountains 1, 4, 11 and 24, Fig. 8). Their thickness is in many cases lower than $4 \mathrm{~mm}$; their lead material has so strongly adhered to the stone that it remained in place when the pipes were removed. Looking at the pipe fragments found and at the shape of the orifices, in many cases it is possible to conclude that the lead pipe reached the front edge of the orifice and the position of the soldered seam along the pipe length was probably at the bottom.

The drawings proposed by various scholars ${ }^{15}$ also present a lead pipe continuing with constant diameter up to the spout. Stanco (2009) published data on the spout stones of the lacus in Alife and assumed that a bronze spout (cannula) was inserted in the orifice and soldered to the supply pipe. This arrangement is to be considered unlikely in Pompeii, since the remains of the lead pipe were found near the front of the orifice as described above, and very few bronze spouts can be seen in the site stores. Furthermore, a reduction of the pipe diameter by means of a bronze spout would have been needed to increase

\footnotetext{
14 The size of the pipe is slightly larger than the spout orifice. This has no specific relevance, considering that other pipelines surveyed along Pompeii walkways present slightly different cross-section measurements between the two ends of the same pipe (e.g. pipe on the walkway close to I.VII.12 -Casa dell' Efebo).

15 Eschebach and Schafer (1983, p. 27), Nappo (2002, pp. 93-94).
} 


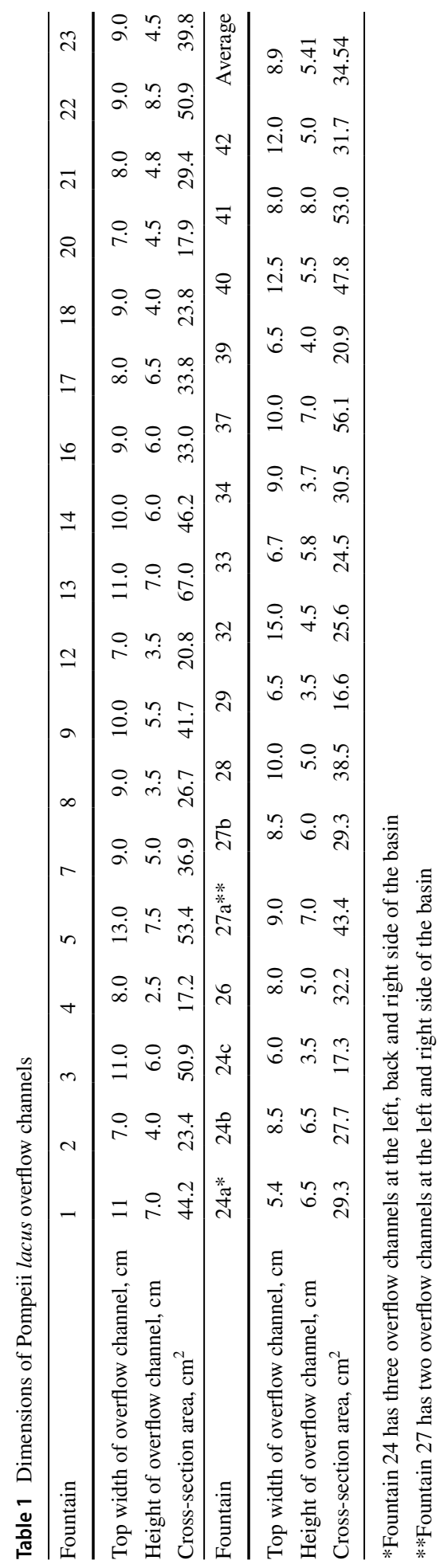



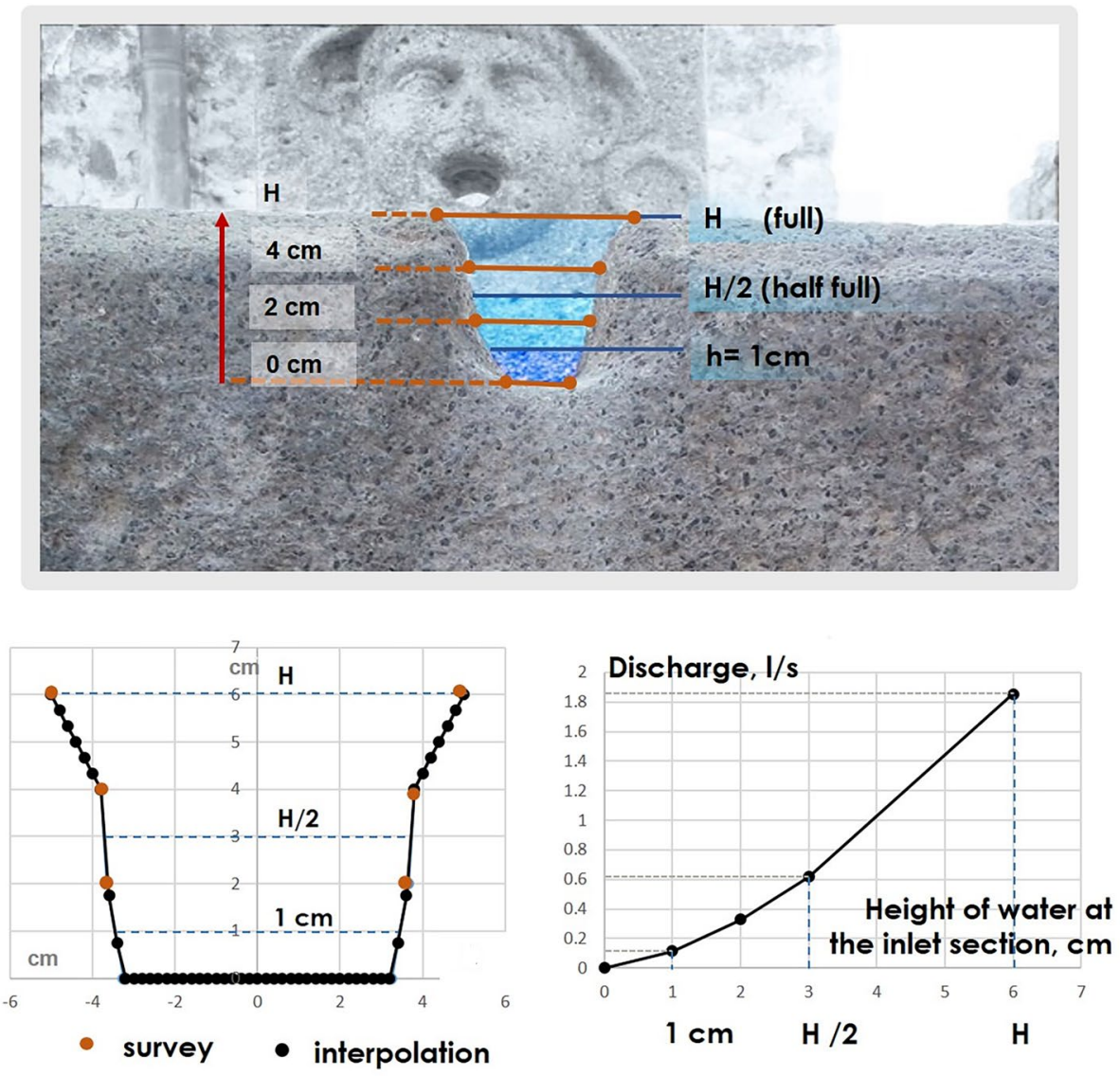

Fig. 6 Fountain 14, above: on-site measurement of the inlet cross-section width, at various levels from the bottom. Below: section profile, constructed through interpolation; discharge curve, showing the discharge of the channel for various water levels

the flow velocity at the jet outlet. As will be described later, the axis of the spout in Pompeii's lacus fountains often points downwards, suggesting that the flow velocities were high enough at the spout, and that there was no need for a smaller-section cannula, but rather for a downwards direction to ensure that the water jet was contained inside the fountain basin.

Table 2 reports the maximum and minimum diameters of the spout orifice for 29 out of the 35 fountains considered in the study (as mentioned earlier, Fountain 10 and 19 were not accessible, and in Fountains 9, 17 and 23 the spout stone is missing or has been replaced by a modern one). In Table 2, the estimate of the size of the supply pipe was obtained from the average diameter of the spout orifice, considering an appropriate pipe thickness. Specifically, it was observed that the pipes surveyed along Pompeii's footpaths and in the site store have a wall thickness ranging between 0.4 and $1 \mathrm{~cm}$, irrespective of the pipe size ${ }^{16}$; therefore, we assumed a constant pipe thickness value of $5 \mathrm{~mm}$ as a reasonable average

16 The pipes measured had internal diameter in the range $1.4-5 \mathrm{~cm}$. 

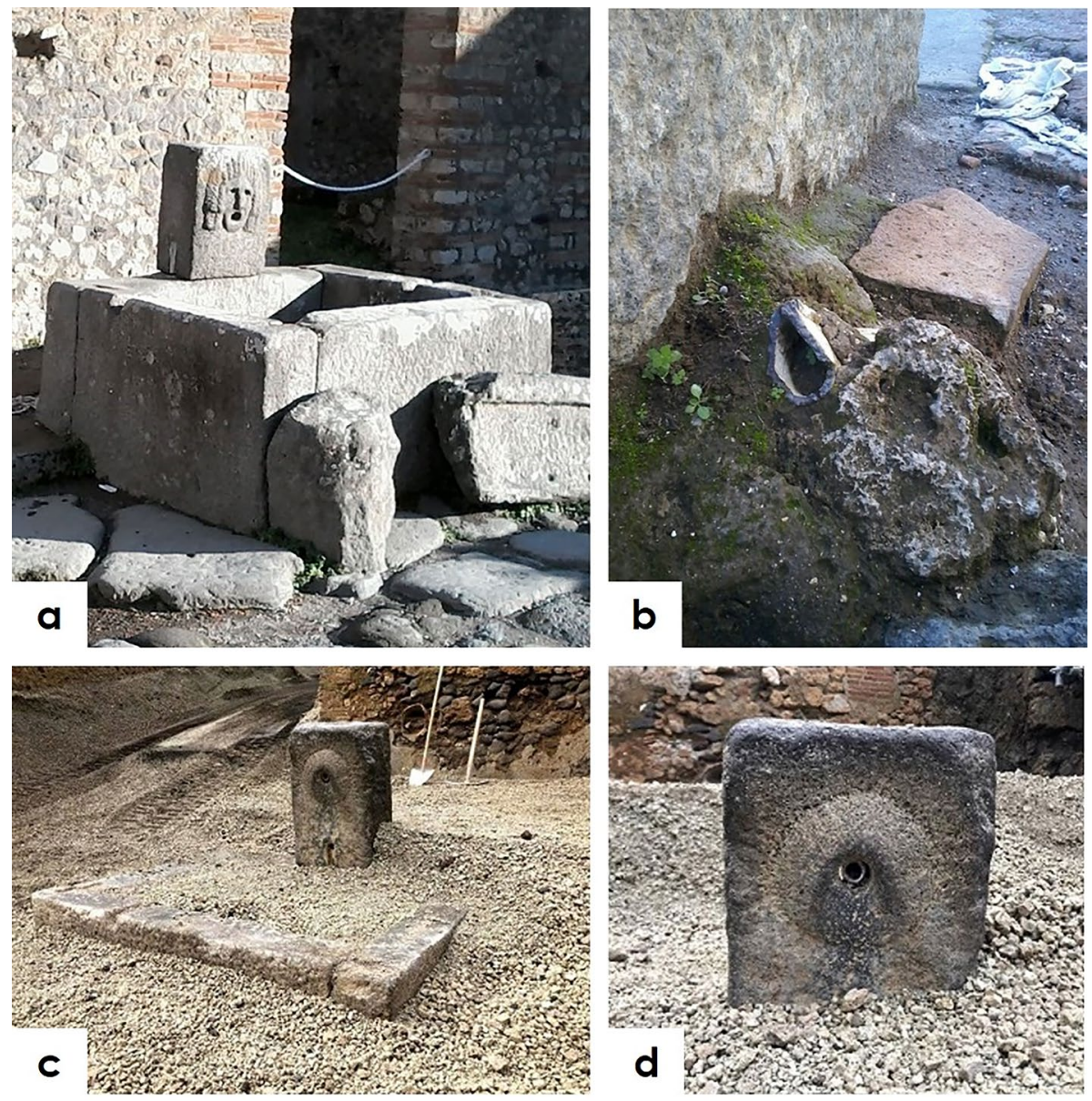

Fig. 7 a Fountain 27 in Vico della Maschera, b cross-section of the supply pipe visible behind the basin, c fountain recently excavated in Regio V and d its spout stone, with the original pipe in place (Parco archeologico di Pompei, www.facebook.com/pompeiisoprintendenza/photos/a.1523717371268809/2245875905 $719615 /$ ?type $=3 \&$ theater)

value. As a result, the average internal diameter varies from $<2 \mathrm{~cm}$ to a maximum of $5 \mathrm{~cm}$, with an average value of $3.31 \mathrm{~cm}$ calculated over 29 fountain basins.

For each pipe, the cross-section area corresponding to the average diameter was divided by the cross-section area of a Roman quinaria pipe $(2.31 \mathrm{~cm}$ internal diameter, corresponding to a $4.189 \mathrm{~cm}^{2}$ cross-section area), to obtain the corresponding capacity of the pipe expressed in Roman quinariae units (last row in Table 2). Figure 9 displays the diameter variability across the 29 fountains, compared with the diameters of the standard Roman pipes described by Frontinus and commented by various modern authors. ${ }^{17}$

The size of the Pompeii fountain supply pipes ranged from smaller than a digitus to larger than a denaria, with the majority of the pipes (14 out of 29) being close to a senaria

17 Frontinus 1.37-63 (in Rogers 2004); Pace (1986, table 8), Nir-El (2017, table 2). 

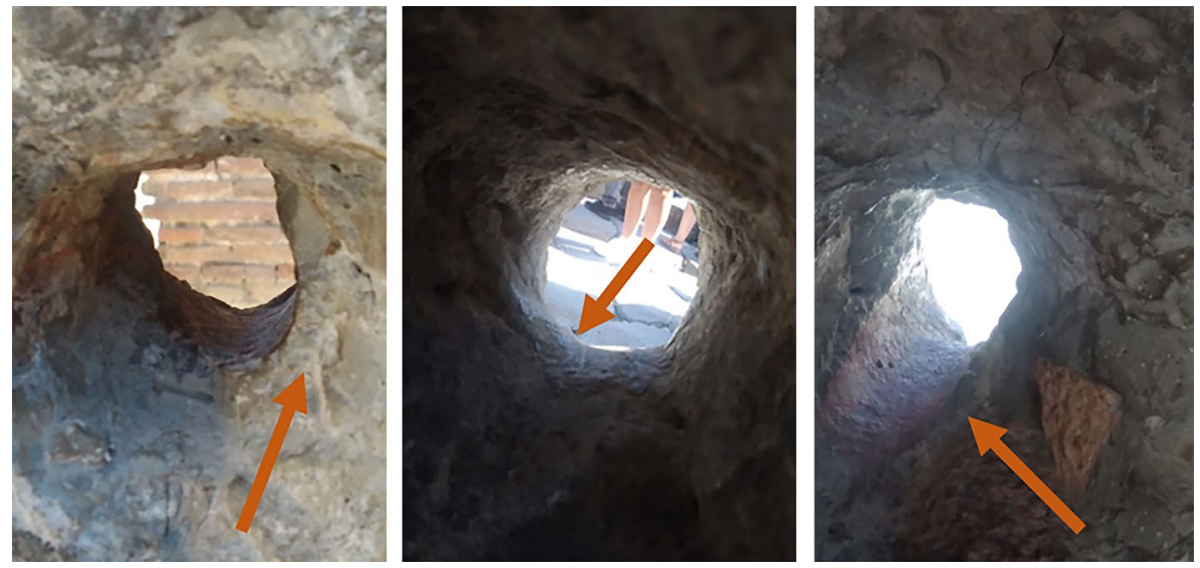

Fig. 8 Small portions of the lead supply pipes found attached to the sides of some spout orifices

or settenaria pipe, of diameter of 2.77 and $3.23 \mathrm{~cm}$ and capacity of 1.42 and 1.87 quinariae, respectively. The average diameter of $3.31 \mathrm{~cm}$, calculated over 29 fountains, is also closer to a settenaria rather than an ottonaria pipe.

The average value of quinariae for the fountains of Pompeii is also compared with the values given by Frontinus for Rome ${ }^{18}$ in Table 3.

In Pompeii the average value of 2.14 quinariae per lacus is very close to the values known for Rome, ranging from 2.13 to 2.46 quinariae. This range of quinariae corresponds to the cross-section area of a supply pipe of diameter $3.3-3.6 \mathrm{~cm}$. The similarity in values possibly confirms the similarity in design and operation of the lacus fountains built in the two Roman towns.

Various other lacus might remain to be found in the unexcavated areas; it was assumed, in this study, that a total of 39 fountains of the lacus type might be present. The possible total supply to 39 lacus fountains is estimated as 83.5 quinariae, based on the average supply of 2.14 quinariae per lacus. This value can be checked against the quinariae computed for the pipes exiting the castellum divisorium at Porta Vesuvio, ${ }^{19}$ using the assumptions (Ohlig 2001, p. 196) that they had diameter of $21 \mathrm{~cm}^{20}$ The cross-section area of two pipes ${ }^{21}$ would total to 164 quinariae, while three pipes would add to 246 quinariae. ${ }^{22}$ The fountains would represent

18 Frontinus, De Aquis 2. 78-96; for a summary of the figures on the supply to the various structures in Rome: Lanciani (1880) and 1975 reprint, Evans (1994), Wilson (2007); on the reliability of Frontinus figures: Bruun (2003).

19 Similar considerations on the quinariae capacity of the pipelines exiting the castellum were made by Hodge (1996), with diameters of 25 and $30 \mathrm{~cm}$.

20 The diameter of the pipe reported by Maiuri (1973) was similar (interior diameters of 22.7 and $17.3 \mathrm{~cm}$ ) while the large pipe visible in the stores is composed of two stretches of internal diameters 16 and $19 \mathrm{~cm}$, 17.5 and $22.5 \mathrm{~cm}$.

21 Maiuri (1973) found a mask/fountain spout inside the castellum and provided drawings of the area in front of the building, underlining the presence of two pipelines directed towards the two east and west orifices in the facade of the castellum; therefore, there is a possibility that the central orifice did not supply the network but a local lacus, usually present at the city gates.

22 Hodge (1996) also calculated the surface of the lower section of the aqueduct at the entrance of the castellum as 179 quinariae. 


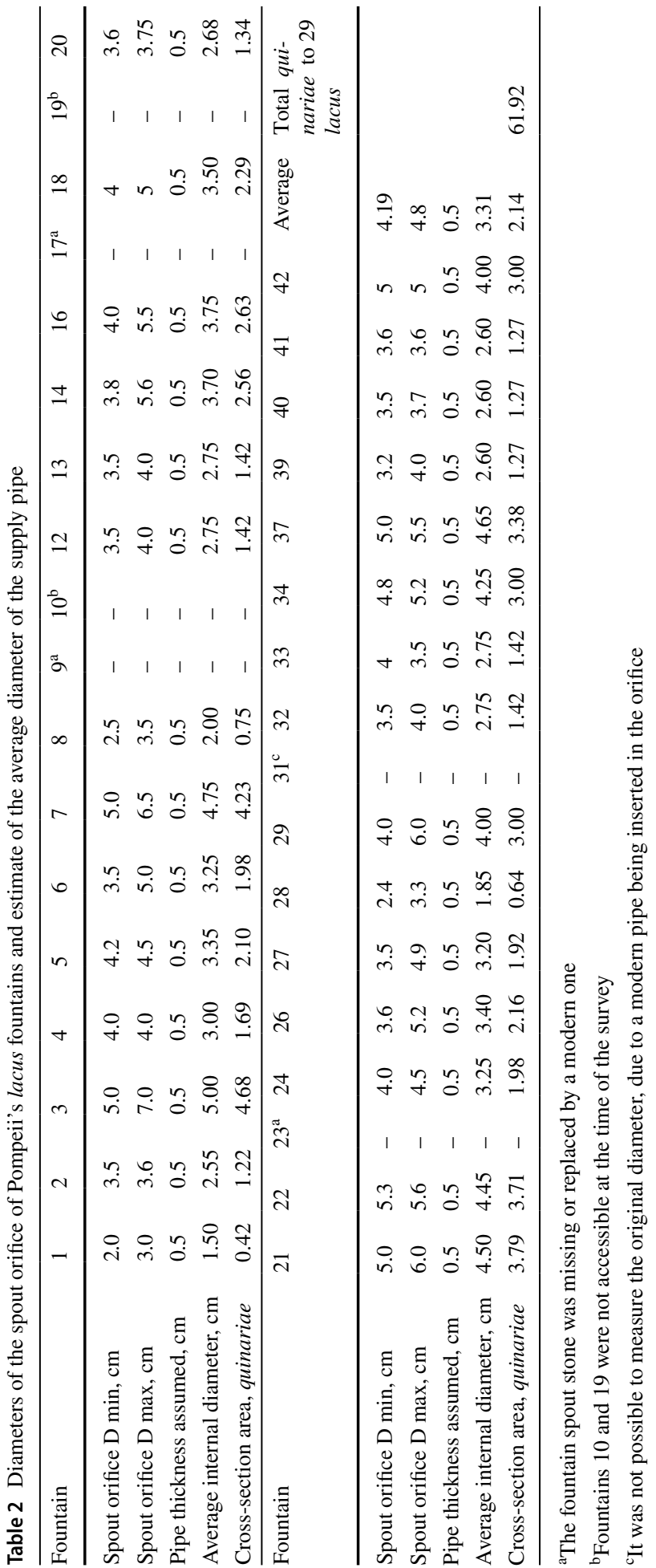




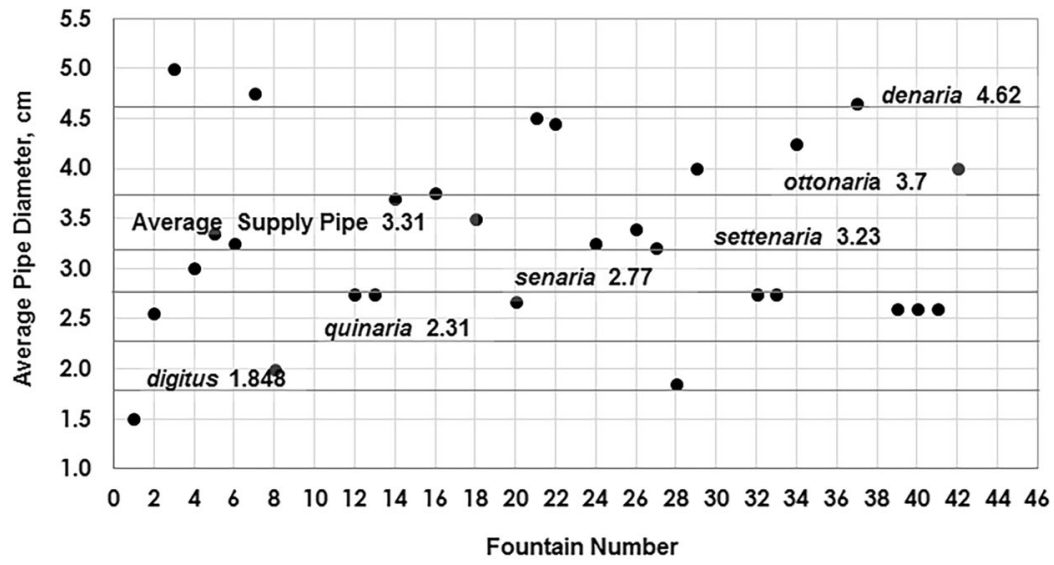

Fig. 9 Distribution of the estimated fountain supply pipe diameter across 29 lacus fountains in Pompeii and comparison with the diameters of the standard Roman pipes

Table 3 The quinariae supply of the lacus fountains in Rome and in Pompeii

$\begin{array}{lllll}\text { Aqueduct Castella Lacus } & \begin{array}{l}\text { To Lacus } \\ \text { Quinariae }\end{array} & \text { To Lacus } & \text { Quinariae/lacus } & \begin{array}{l}\text { Corresponding } \\ \text { pipe diameter, } \\ \text { cm }\end{array}\end{array}$

\begin{tabular}{lrrrrrrr}
\hline Aqua Appia* & 699 & 20 & 92 & 226.0 & 32.3 & 2.46 & 3.62 \\
Anio Vetus* & 1509 & 35 & 94 & 218.0 & 14.5 & 2.32 & 3.52 \\
Aqua Marcia* & 1472 & 51 & 113 & 256.0 & 17.4 & 2.27 & 3.48 \\
Aqua Tepula* & 331 & 14 & 13 & 32.0 & 9.7 & 2.46 & 3.63 \\
Aqua Julia* & 597 & 17 & 28 & 65.0 & 10.9 & 2.32 & 3.52 \\
Aqua Virgo* & 2304 & 18 & 25 & 51.0 & 2.2 & 2.04 & 3.30 \\
Aqua & 3498 & 92 & 226 & 482.0 & 13.8 & 2.13 & 3.37 \\
$\quad$ Claudia/A. & & & & & & & \\
$\quad$ Novus* & & & $39 ?$ & $83.5 * *$ & $?$ & 2.14 & 3.31 \\
Pompeii & & & & & & & \\
\hline
\end{tabular}

*Values for the aqueducts of Rome from Frontinus

**Obtained by multiplying the average 2.14 quinariae per lacus by the total number of lacus including the ones in the unexcavated areas, assumed as 39

$51 \%$ of the town water supply in the first case and $34 \%$ in the second case. Compared with the figures for Rome, the latter value would be more likely than the former. We do not know yet if, in Pompeii, the fraction of the supply directed to the various users was significantly different from the fraction in Rome; future research will allow to identify the water consumption of the various types of buildings in Pompeii. 


\section{The discharge of the lacus overflow channels}

The curve describing the relation between the height of water in the overflow channel and the flowrate in the channel, known as rating curve, can be obtained by computing three discharges for the three conditions: $1 \mathrm{~cm}$ water height at the channel inlet, water height equal to half of the inlet cross-section height $(H / 2$, half-full channel) and water height equal to the inlet cross-section height ( $H$, full channel). For each height condition, the corresponding flowrate is obtained as the sum of the flowrates of unit subsections of height $h_{i}$ and width $b_{i}$ according to the following formula for broad crested weir ${ }^{23}$

$$
Q=\sum_{i} 0.385 b_{i} h_{i} \sqrt{2 g h_{i}}
$$

where $g$ is the acceleration of gravity $\left(9.81 \mathrm{~m} / \mathrm{s}^{2}\right)$.

The three flowrates obtained might be assumed as a maximum value for the fountain minimum continuous supply, intermediate continuous supply and maximum continuous supply, respectively; in fact there is no certainty that the fountains were supplied with a constant flowrate throughout the day.

Plotting in a chart the value of discharge corresponding to each water level, we obtained the rating curve for the overflow channels of the 31 fountains (see previous Fig. 6). Figure 10 shows examples of the various shapes and sizes of the inlet cross-section and the corresponding rating curves.

The discharges calculated for each channel and for the three water heights at the inlet $(1 \mathrm{~cm}, H / 2$ and $H$ ) are given in Table 4 . Overall, the minimum discharge, corresponding to water height of $1 \mathrm{~cm}$, ranges between 0.03 and $0.15 \mathrm{l} / \mathrm{s}$. The intermediate discharge ranges between 0.12 and $0.95 \mathrm{l} / \mathrm{s}$. The maximum discharge, corresponding to $H$, ranges between 0.45 and $2.921 / \mathrm{s}$.

\section{The trajectory of the water jet for discharge validation}

The values of flowrate computed using the geometry of the overflow channels can be verified, on the base of the corresponding flow velocity and the trajectory of the water jet from the spout hole. A subset of 28 fountains (Table 5) is analysed, corresponding to those fountains for which geometric data on both the spout orifice and overflow channel(s) are available. For each fountain and each flowrate (minimum continuous supply, intermediate continuous supply and maximum continuous supply) the flow velocity at the spout is computed with the following expression:

$$
V=\frac{Q}{A}
$$

\footnotetext{
23 The formula applies to the condition of the weir crest much larger than the height of water over the weir, so that the critical height is $2 / 3$ of the water height, which in turns produces a 0.385 coefficient (see for example Chadwick et al. 2013, p. 457). Although a second experimental coefficient could be applied, the formula is considered sufficiently accurate for this case. The cross-section is divided in vertical stripes of $0.2 \mathrm{~cm}$ and the sum of the discharges through each stripe is considered as the discharge for the crosssection.
} 
where $Q$ is the discharge estimated for the overflow channel(s) and $A$ is the cross-section area of the supply pipe. The values of velocity are shown in Table 5, columns 6-8. The horizontal distance from the spout at which the jet impacts the water in the basin $\left(X_{j e t}\right)$ is calculated, from the above velocity and knowing the spout height over the top of the basin $\left(H_{s}\right)$ with the formula ${ }^{24}$ :

$$
X_{j e t}=V \sqrt{\frac{2 H_{s}}{g}}
$$

The values obtained for the distances $X_{\text {jet }}$ are shown in Table 5, columns 10-12. Column 13 contains the values of the width of the basin; columns 15-17 contain the ratio between the distance of the water jet and the basin width $\left(X_{j e t} / W\right)$. In dark green are identified the values equal or above one, which means that the jet is not contained within the basin. This is the case for Fountains 1, 13, 24, 27 28, 40 and 41.

Column 14 identifies with a " $Y$ " notation the fountains for which an evident downward direction of the spout axis was observed. For Fountains 27 and $40 X_{j e t} / W$ is very close to 1 and the spout axis is oriented downwards, which most likely caused the actual $X_{j e t} / W$ value to be lower than 1 . Therefore, their corresponding maximum continuous supply discharge values can be considered reasonable. In Fountains 1 and 28, the small supply pipe diameter $(<2 \mathrm{~cm}$, diameters marked in yellow in Table 5 , column 2$)$ causes the velocity values to be significantly larger than in the other fountains.

The final rows of Table 5 contain the average values, calculated over all the 28 fountains considered or calculated with the exclusion of the 7 fountains with improbable values (highlighted in green). With the exclusion of the improbable values, the computed average maximum continuous supply of the fountains is $1.18 \mathrm{l} / \mathrm{s}$; the intermediate continuous supply is $0.43 \mathrm{l} / \mathrm{s}$ and the minimum continuous supply is $0.08 \mathrm{l} / \mathrm{s}$. The average of the maximum velocities at the spout is $1.25 \mathrm{~m} / \mathrm{s}$ and the distance from the spout at which the water jet hits the water surface in the full basin is $0.31 \mathrm{~m}$, or $34 \%$ of the basin width. The variability of discharge across the various ranges of the spout diameters is displayed in Fig. 11.

\section{Average retention time of water in the fountain basins}

The lacus fountains, with their small but available storage capacity, could compensate for some irregularities in the supply and periods of flow interruption. We expect that, to maintain an acceptable water quality and avoid temperature increase ${ }^{25}$ in the warmer periods of the year, the residence of the water in the basin for long times had to be controlled. At present, there is no information on possible values of residence time because none of the

\footnotetext{
24 The formula is derived from the two equations describing the motion of a free water jet, discharged from an orifice with velocity $\mathrm{V}$, in the $\mathrm{x}$ and $\mathrm{z}$ directions, and then eliminating the time variable between the two (see for example Som and Biswas 2008, p. 229).

25 Some fountains are located on the most shaded side of the street, other basins are exposed to the sun, so that in the summer the water temperature could have been over $20{ }^{\circ} \mathrm{C}$, favouring microbiological overgrowth. A thermal modelling of the basins would be useful to assess the patterns of temperature and velocity inside the draw basin; this type of modelling was not included in the present study.
} 


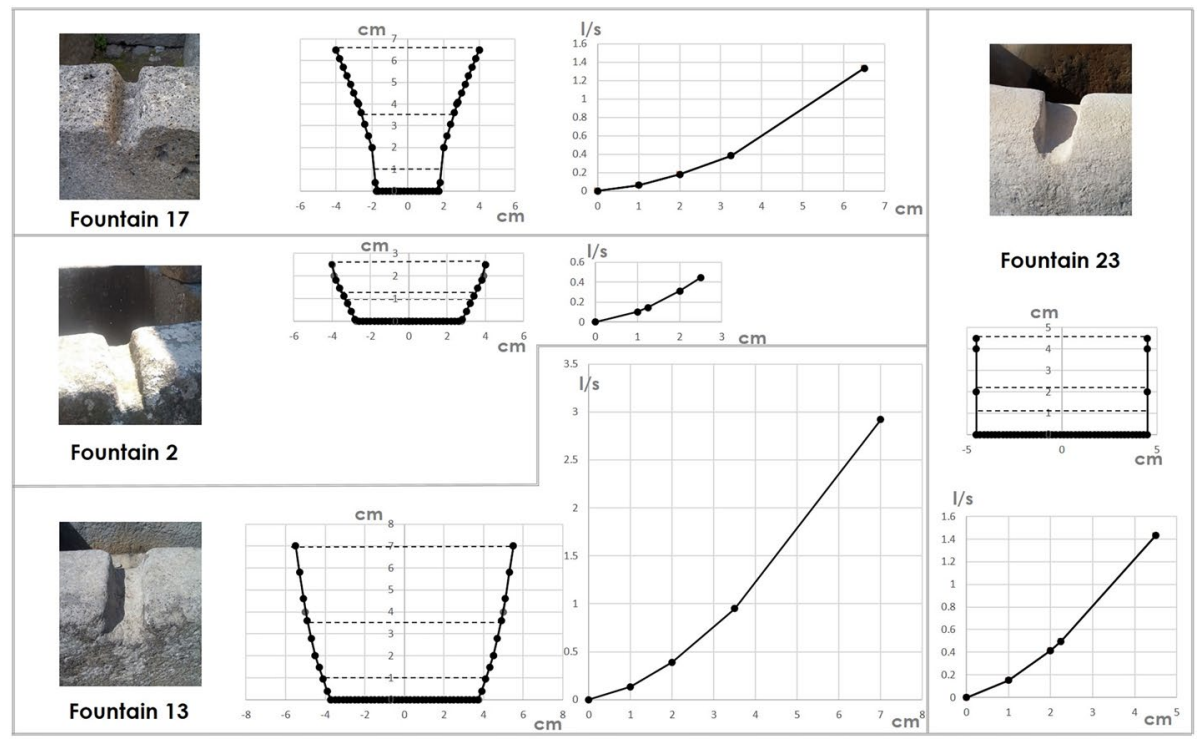

Fig. 10 Examples of the variability across the overflow channel cross-section shape, size and corresponding discharge curve. Fountains 17 and 2 (among the smallest for cross-section and discharge), Fountain 13 (largest maximum discharge) and Fountain 23 (rectangular inlet cross-section and converging channel) are considered

published study have discussed the flow field distribution inside an ancient fountain draw basin. ${ }^{26}$

The water retention time, also known as residence time or hydraulic retention time (HRT), is computed as the ratio between the fountain basin volume and the continuous flowrate through it:

$$
H R T=\frac{\text { Volume }}{\text { Discharge }}
$$

The larger the basin or the lower the flowrate, the less rapid is the water circulation and mixing in the basin. Three values of hydraulic retention time are obtained for each fountain basin, for the three discharge conditions; the results are summarised in Table 6 and plotted in the chart of Fig. 13.

The fact that the basin supply and the basin volume were related through the hydraulic retention time, becomes clear from consideration of the modifications to some fountains, in ancient times (Table 6 and Fig. 12). In the case of Fountain 32 (Fig. 12a) the volume of the basin was not altered, however a $5 \mathrm{~cm}$ orifice was pierced below the original overflow channel; the calculations have excluded that both the overflow channel and the orifice could operate simultaneously, since in this case the discharge would have been so large that trajectory of the water jet at the spout would have surpassed the basin width. When the water level was up to $2 \mathrm{~cm}$ above the orifice lower edge, for a retention time between 24

\footnotetext{
${ }^{26}$ The importance of assessing the velocity and retention time in the lacus of large nymphaea fountains was outlined by Richard (2016), nevertheless he did not provide any estimate.
} 


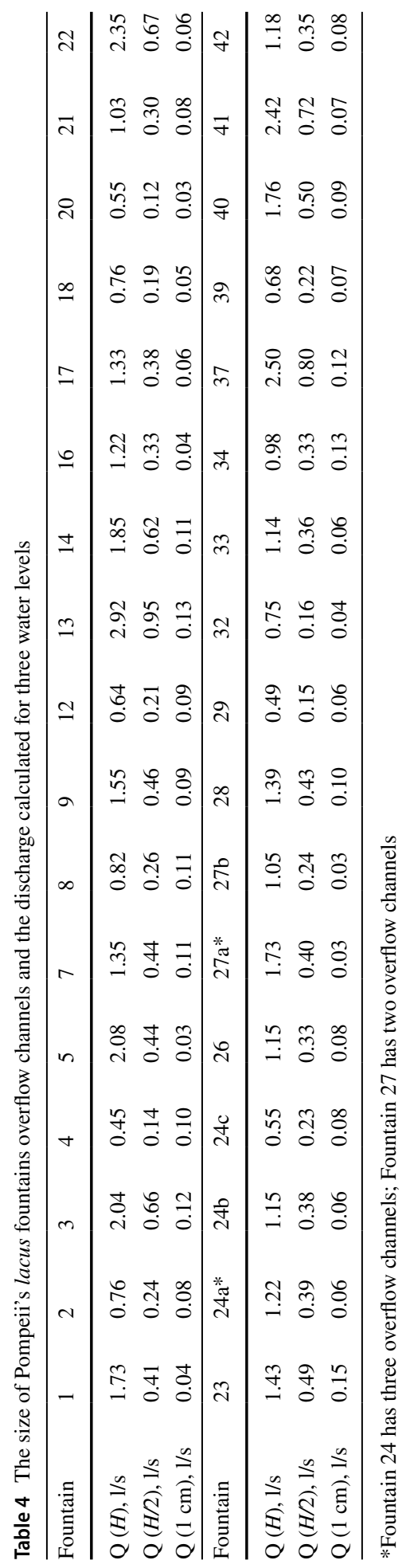




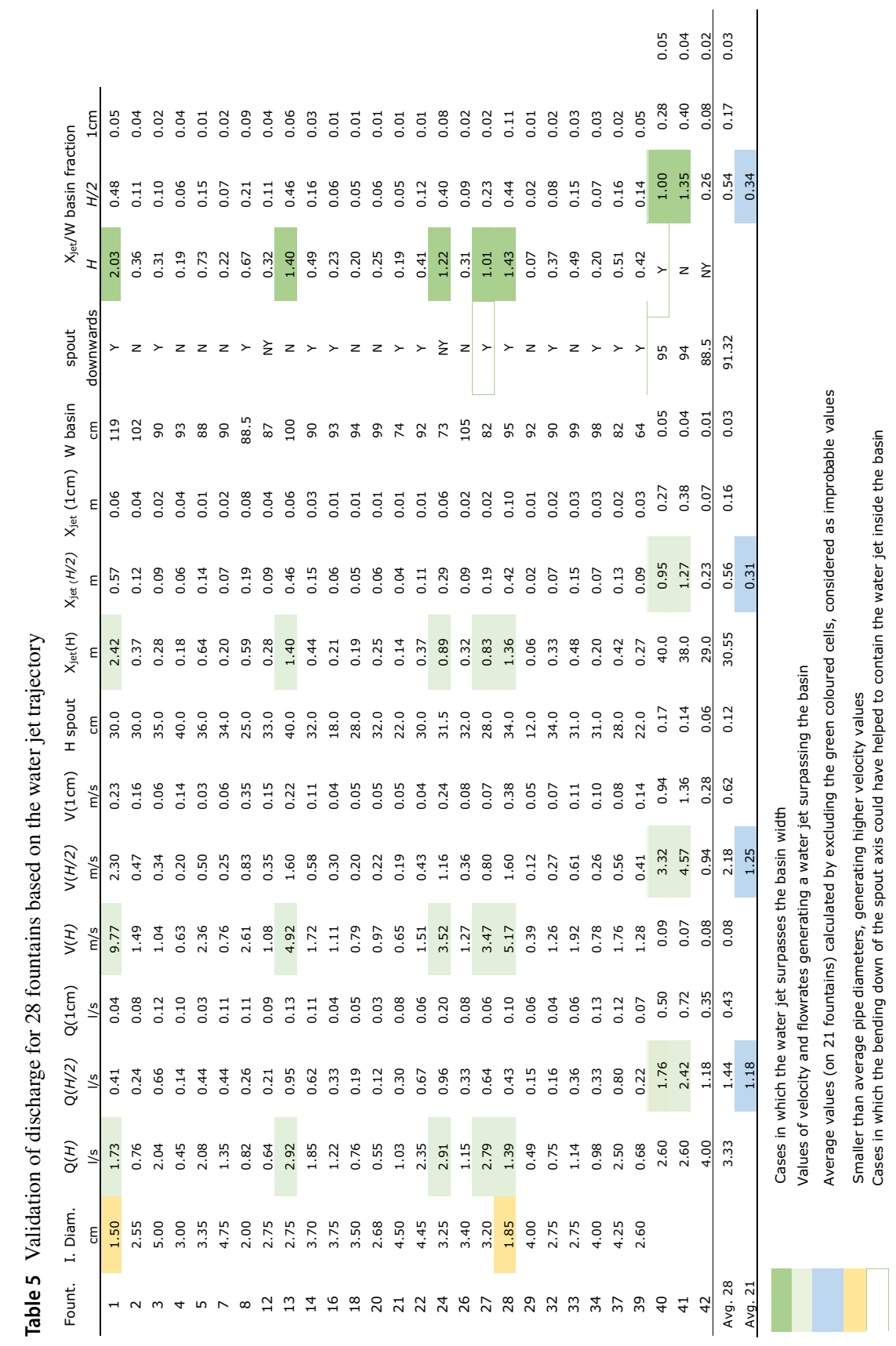




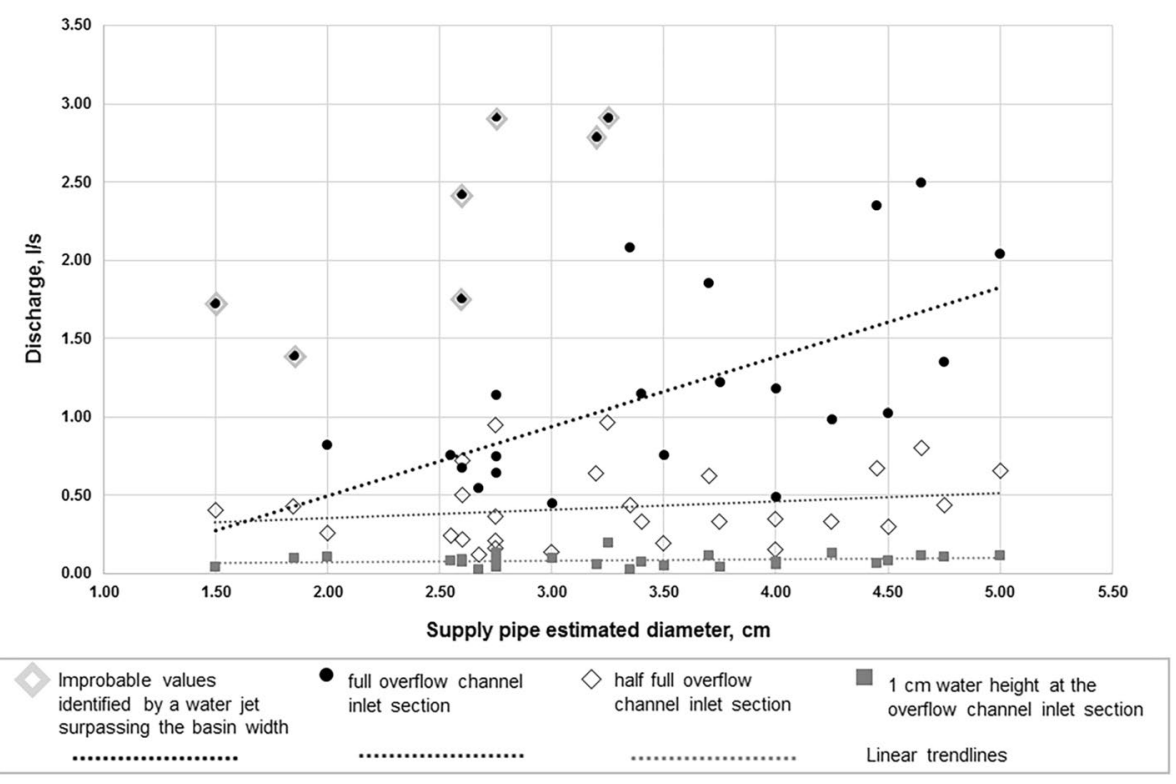

Fig. 11 Relation between the discharge of the overflow channel and the fountain supply pipe diameter

and 92 min, obtained when the original channel was in function, the discharge of the orifice would have been about $50 \%$ lower than the discharge of the original overflow channel.

Three fountain basins (Fountains 37, 24 and 6) were reduced in volume, compared to the original size, by raising the level of the basin bottom; the new and the original bottom drain holes remain visible. The depth of the basin of Fountain 37 (Fig. 12b) was decreased from 72 to $60 \mathrm{~cm}$, with a reduction of volume of $16.8 \%$; for this fountain only it was found that the original spout orifice of $5.25 \mathrm{~cm}$ was reduced to $2.5 \mathrm{~cm}$ (Fig. 12b); with the flowrate proportional to the cross-section area, the reduced flowrate would have been around $22.7 \%$ of the original flowrate. In the case of Fountain 24 (Fig. 12c) the bottom was raised of $28 \mathrm{~cm}$, causing the basin volume to be reduced from 0.74 to $0.45 \mathrm{~m}^{3}$. The original retention time corresponding to the three overflow channel discharges was 4.2, 22.7 and 62 min, closer to the other lacus retention times than the values corresponding to the reduced volume; this would point at a reduction of the flowrate in a similar proportion of the volume reduction, from the range $0.2-2.9 \mathrm{l} / \mathrm{s}$ to the range $0.12-1.8 \mathrm{l} / \mathrm{s}$. In the case of Fountain 6 (Fig. 12d) the new basin bottom was $16 \mathrm{~cm}$ higher than the original one, causing a reduction of about $18.5 \%$ from the original volume; we expect that the flowrate decreased too, however this fountain lacks a regular overflow channel, therefore it was not included in Table 6. For the above fountains two values of retention time in the current and original condition were included in Table 6 and in the chart in Fig. 13.

With the exclusions of the flowrates highlighted in Table 5, and considering the original volume for the three basins modified in time, the minimum HRT (corresponding to the maximum continuous discharge) ranges between 3 and $27 \mathrm{~min}$, with an average value of $11.7 \mathrm{~min}$. For the intermediate water level (corresponding to the intermediate discharge), the HRT ranges between 11 and $119 \mathrm{~min}$, with an average value of $37.8 \mathrm{~min}$. For the lowest flowrate (minimum continuous discharge) the average retention time is calculated as $3 \mathrm{~h}$, ranging between 0.5 and $4.7 \mathrm{~h}$. In fact, 20 out of 31 values remain below $2.9 \mathrm{~h}$. From 


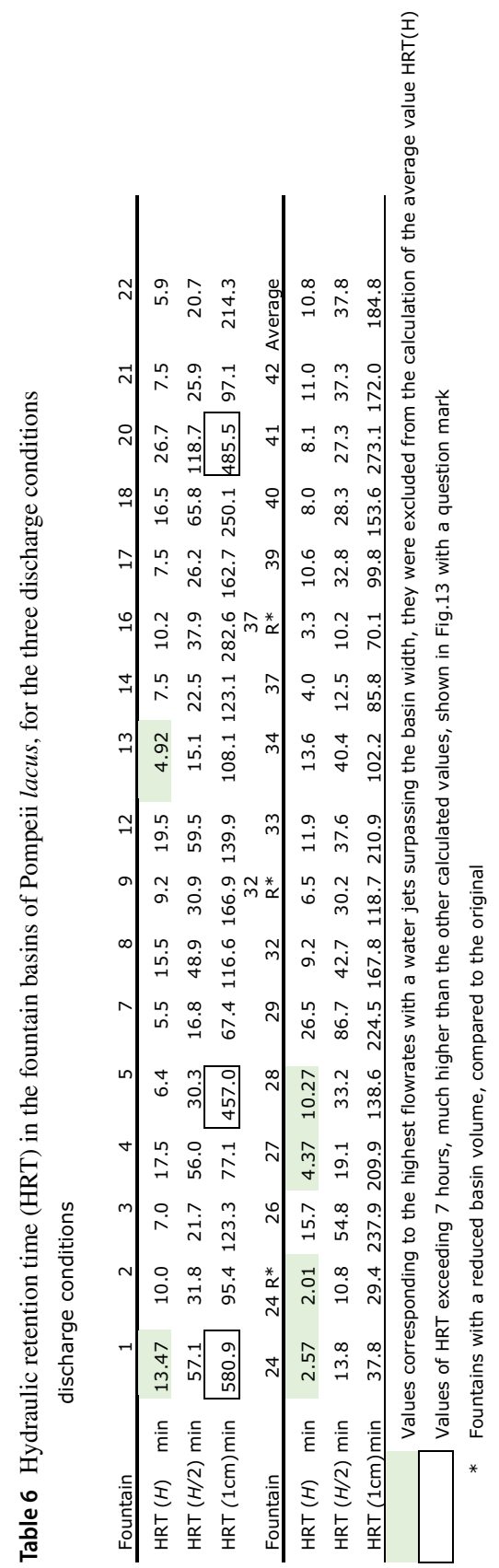



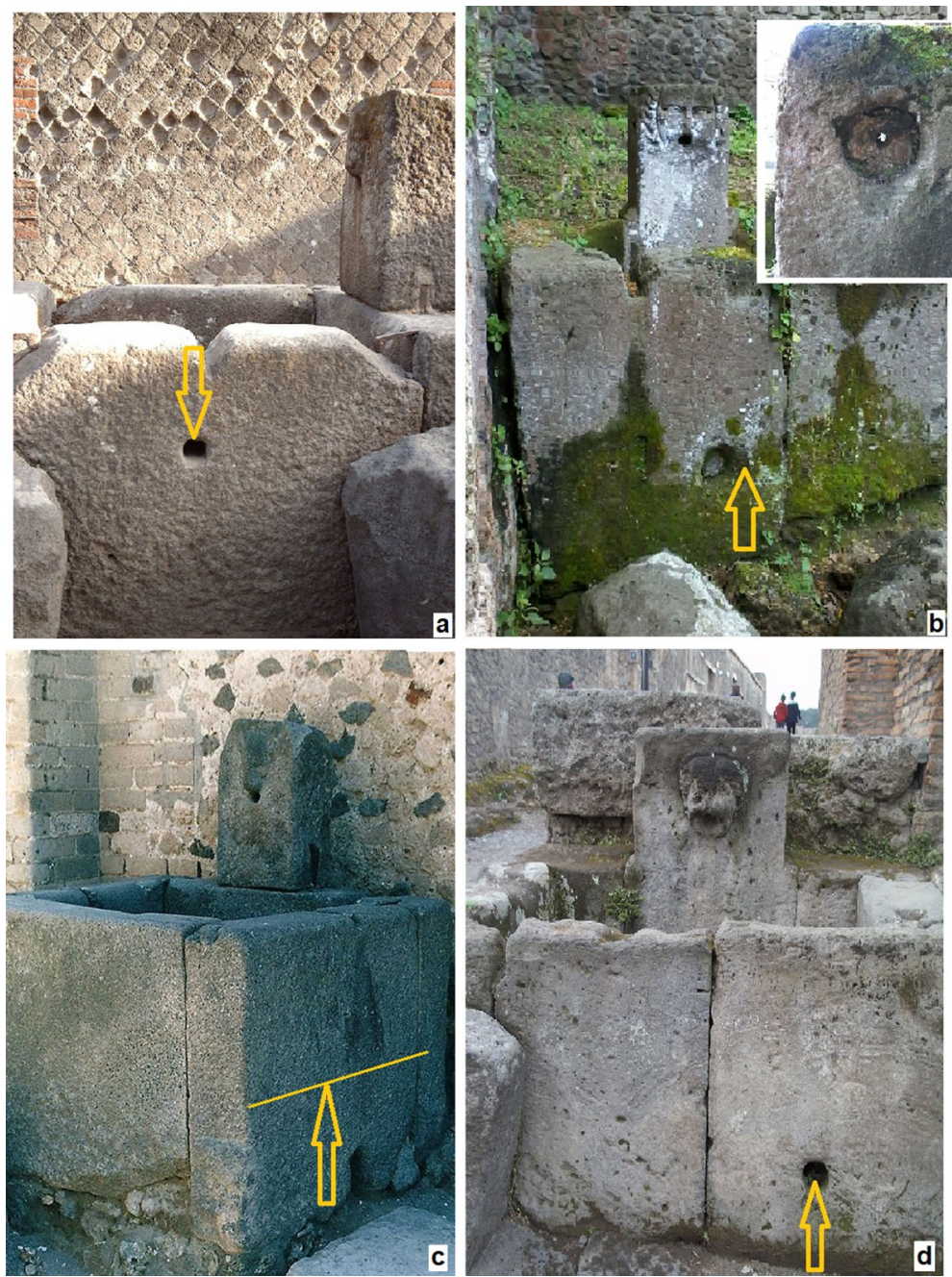

Fig. 12 Fountains presenting elements modified in ancient times. a Fountain 32 modified overflow with the piercing of a circular hole below the original channel, b Fountain 37 modified basin volume (bottom elevation) and reduction of the spout orifice, $\mathbf{c}$ Fountain 24 modified basin volume (bottom elevation), d Fountain 6 modified basin volume (bottom elevation)

Fig. 13 it is evident that three values (Fountains 1, 5 and 20) of the retention time are higher than $7 \mathrm{~h}$ : it can only be speculated for those three fountains that their flowrate was most of the time larger than their calculated minimum continuous discharge.

From the discussion presented on the retention time, it comes clear how the permanence of water in the fountain basin, under solar radiation would have resulted in an alteration of the water temperature: was the hydraulic retention time the variable determining the size of the draw basin in any ancient fountains, especially in the warmer climates ${ }^{27}$ ?

27 In Pompeii the basins' volume ranges from 0.4 to $1.2 \mathrm{~m}^{3}$ with an average of $0.7 \mathrm{~m}^{3}$. Looking at the size of some basins found in Gaul: Bavay lacus (Loridant 2004): base 1.75×1.93 m; Lyon, clos du Verbe Incarné (Delaval and Savay-Guerraz 2004) $1.75 \times 1.15 \times 1.05$ m; Saint Romain en Gal (Brissaud 2004): 


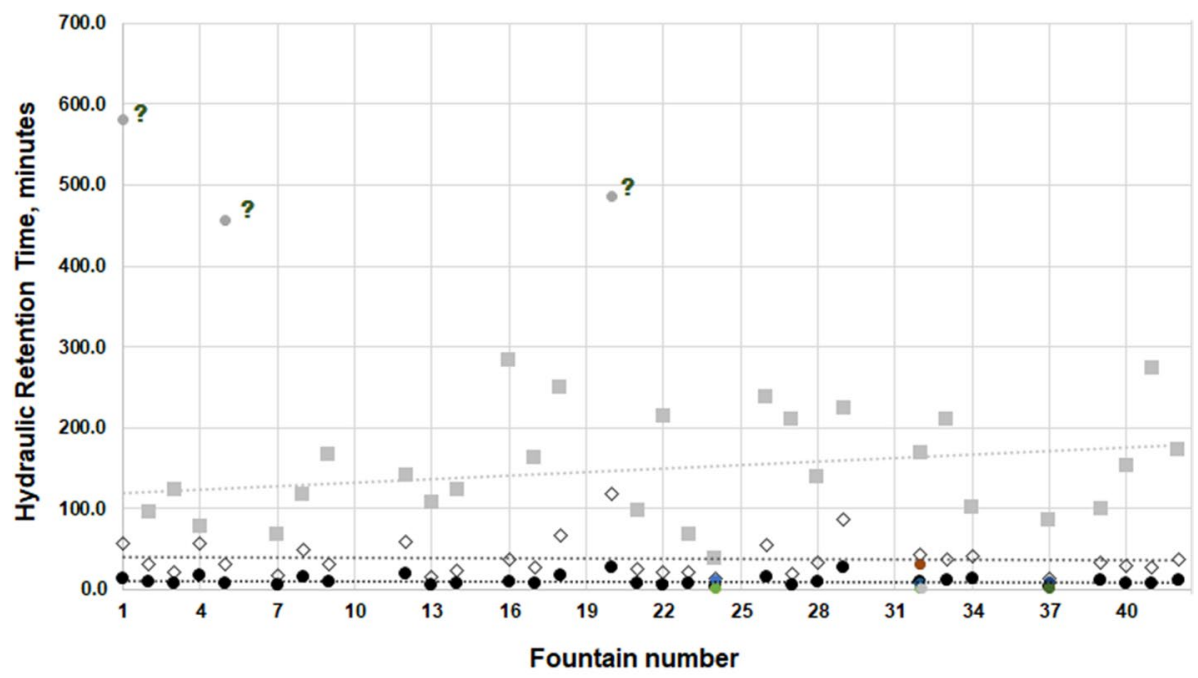

overflow channel $\diamond$ overflow channel with with full inlet

half full inlet
$1 \mathrm{~cm}$ water height at the channel inlet

Linear trendlines

Fig. 13 Values of hydraulic retention time in the fountain basins for the three discharge conditions considered. The question marks identify the values higher than $7 \mathrm{~h}$, the coloured dots identify the HRT for Fountains 24, 32 and 37 corresponding to a reduced basin volume

\section{Discussing the lacus operation and the total water supplied to the town fountains}

The simple lacus basin, as well as the front draw basin in other, larger fountains, was designed to overflow; this is an assumption accepted by all scholars. ${ }^{28}$

Once that the lacus basin was filled (for example during the night), a continuous trickle of water might have been sufficient to maintain it full. In Pompeii, the trickle discharge would correspond to the calculated average minimum discharge activating the overflow, $0.08 \mathrm{l} / \mathrm{s}$. This flowrate would be similar to the one supplying the lacus of Timgad and Herculaneum shown in Fig. 14. Once a basin with an average depth of $0.69 \mathrm{~cm}$ was full

Footnote 27 (continued)

Rue de Portique $1.70 \times 3.20 \mathrm{~m}$, Rue des Thermes $1.10 \times 2.55 \mathrm{~m}$; Poitiers (Gerber and Bambagioni 2009) $1.75 \mathrm{~m}^{3}$ and $2.4 \mathrm{~m}^{3}$. In Paestum (Schmölder-Veit 2009, p. 111) basins have also dimensions larger than Pompeii: decumanus maximus E $1.3 \times 2.5 \times 0.64 \mathrm{~m}$ or $1.8 \mathrm{~m}^{3}$; cardo maximus $\mathrm{N} 1.40 \times 1.21 \times 0.77 \mathrm{~m}$ or $1.19 \mathrm{~m}^{3}$. The larger fountains and nymphaea, equipped with front draw basins of up to $80 \mathrm{~m}$ in length, might have been supplied with higher flowrates, so that similar retention times were maintained: more information and research is needed in this regard.

${ }^{28}$ One demonstration that lacus were kept full is also the fact that in some monumental fountains the front full lacus discharged into secondary front labra or basins through its overflow, as in the Tritons nymphaeum in Hierapolis and the angle fountain of Althiburos (Lamare, Le fontaines monumentales en Afrique Romaine 2019, Fig. 136), These secondary basins could not operate without the main lacus being full. 
(average basin size $0.90 \times 1.12 \mathrm{~m}$ ), the flowrate of $0.08 \mathrm{l} / \mathrm{s}$ would fill a $5 \mathrm{~L}$ container, ${ }^{29}$ placed under the jet, in around $1 \mathrm{~min}$, and allow to fill almost $58 \times 5 \mathrm{~L}$ containers per hour, without any drop in the level of water in the basin. Possibly at some hours of the day the number of users could have been larger: further $50 \times 5 \mathrm{~L}$ containers filled per hour would have caused a $25 \mathrm{~cm}$ drop.

Therefore, at the minimum 'trickle' of water, 108 containers of $5 \mathrm{~L}$ could be filled per hour, before the level dropped below two-thirds of the basin average depth. The intermediate average discharge of $0.43 \mathrm{l} / \mathrm{s}$, calculated for the case of overflow channels half full, is a considerable discharge, being almost threefold the maximum quantity of water discharged by a kitchen tap. It would have allowed to fill almost $310 \times 5 \mathrm{~L}$ containers per hour, without any drop in the water level. Therefore, the chance that the basins were maintained quite full during the day (if the mentioned discharges were assured) was possible, in practice.

When the lacus ran full, the supply coincided with the overflow channel discharge; in limited periods of time the lacus water level could have been lower than the overflow level, however there are indications that the target was to maintain some water discharge even at low supply as explained in the previous section, regarding the retention time and the changes in some basins' volume.

We cannot assume that the supply was constant throughout the day, however we do not know how it varied within the day. The pipelines connecting the water towers to the public fountains were found in limited lengths and no taps were ever found; we assume that some way to stop the supply to the basin was needed to perform regular maintenance, however there is not enough information at present, to understand if any fountain was disconnected during some parts of the day or in the night. The water marks in the basins are not sufficiently evident to identify the most recurrent level of the water during the regular fountain operation.

We would like to draw some considerations on the flowrates needed in the case where all the lacus of the town (assumed as 39 in number) operated simultaneously, with the three discharges calculated in this study. The total supply, calculated by multiplying the average discharges by 39 , would be $3.1,16.8$ and $46.0 \mathrm{l} / \mathrm{s}$ for the minimum, intermediate and maximum discharge. The values exclude the supply to other types of public fountains, different from a lacus, such as the arch of Germanicus at the north east end of the forum.

The values can be compared with the discharge of the aqueduct channel, supplying the castellum divisorium at Porta Vesuvio. Data on the geometry of the channel was made available by Ohlig (2001, p. 23 and chapter 4), for a length of about $112 \mathrm{~m}$ from its outlet. The channel width and the bottom level ${ }^{30}$ measured at the various cross-sections, was entered in a series of steady open channel flow simulations, considering various discharge values. ${ }^{31}$ The resulting water surface profiles were compared with the data on the sinter deposit marks on the two sides of the channel, ${ }^{32}$ finding out which flowrate generated the best matching profile.

\footnotetext{
${ }^{29}$ For example, a hydria type of container, ranging from 20 to $40 \mathrm{~cm}$ in height might have carried up to 6 $\mathrm{L}$ of water.

${ }^{30}$ Ohligh, op. cit, 299-301.

31 The HEC-RAS open channel modelling (https://www.hec.usace.army.mil/software/hec-ras/) included 85 cross-sections, starting from the first linear mark in the bottom of the castellum divisorium tank, up to $87 \mathrm{~m}$ upstream along the channel. Two values of Manning's roughness coefficient of 0.014 and $0.019 \mathrm{~s} /$ $\mathrm{m} 1 / 3$ (Motta et al. 2017) were used. Since we could not validate the data on site and confirm the precision of our calculations, the results of the simulations are proposed only as a reference value and no other detail is given within this study.

32 Ohlig, op. cit. pp. 302-303.
} 

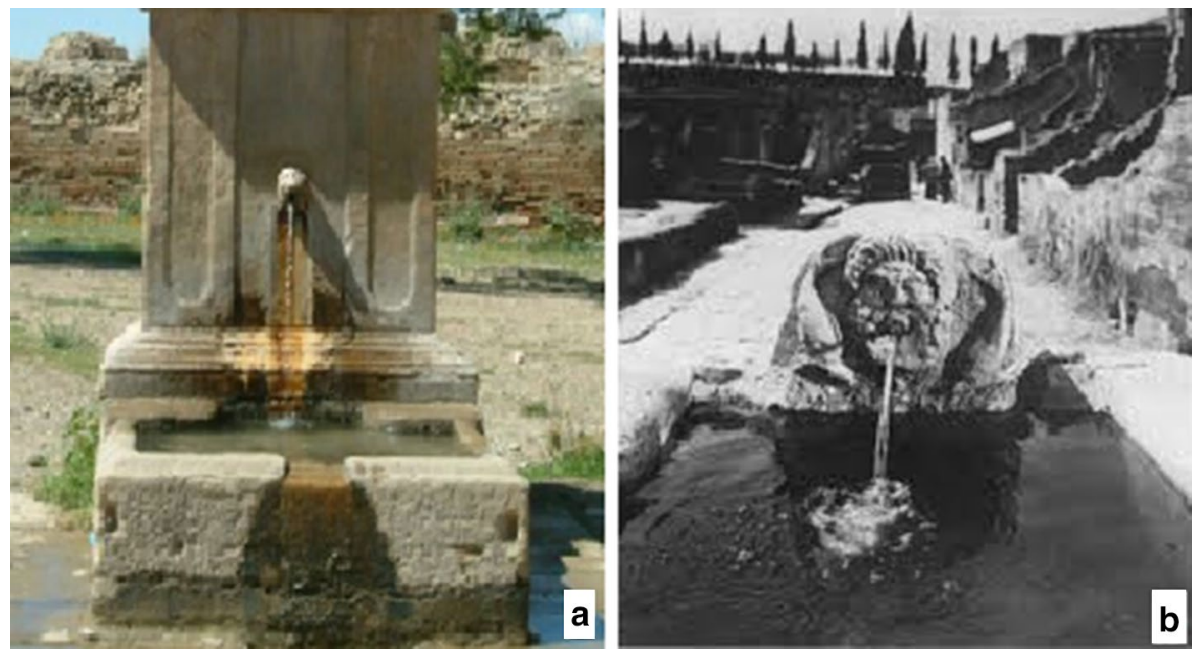

Fig. 14 Example of overflowing lacus supplied with a flowrate close to the minimum average discharge calculated for Pompeii fountains. a Timgad (courtesy of El-hadi Tebbane, flickr public collection), b Herculaneum (Hartnett 2008)

There was not a good agreement between the sinter marks and the profile within the last $4 \mathrm{~m}$ of the channel, having a reduced cross-section; for the rest of the channel the lowest flowrate value could be identified as $20-251 / \mathrm{s}$, the same value proposed by Ohlig, while the highest flowrate was close to $60 \mathrm{l} / \mathrm{s},{ }^{33}$ higher than the value $45 \mathrm{l} / \mathrm{s}$ proposed by Ohlig.

The 39 lacus minimum total discharge of 3.1 1/s represented $14 \%$ of the minimum channel discharge and $5 \%$ of the maximum channel discharge. The lacus intermediate total discharge of $16.8 \mathrm{l} / \mathrm{s}$ represented $67 \%$ of the aqueduct channel minimum discharge and $28 \%$ of the aqueduct channel maximum discharge. The lacus maximum total discharge of $46 \mathrm{l} / \mathrm{s}$ was almost double the minimum aqueduct channel discharge and $76.6 \%$ of the maximum aqueduct channel discharge, which would have left $23.4 \%$ (or $14 \mathrm{l} / \mathrm{s}$ ) to other public and private uses. ${ }^{34}$ Given that the data available for the lacus in Rome identifies a percentage of the total aqueduct discharge between 2.2 and $32 \%$ (Table 3), we are inclined to conclude that the minimum and intermediate lacus discharges, calculated in this study, might have been more probable than the maximum supply values. Without a quantification of the water used by private houses, public buildings and workshops, any other discussion on Pompeii water demand remains purely abstract.

So, if the most likely discharge was close to the minimum and intermediate values, why the overflow channels were oversized? The overflow channel might have been designed to readily discharge an occasional surplus water in the water towers, acting as a pressure

\footnotetext{
${ }^{33}$ It is not possible to provide more precise results without carrying out a new channel survey. However it is unlikely that the channel could carry more than $60 \mathrm{l} / \mathrm{s}$ in its final layout.

34 Various authors have estimated that up to 100 houses in Pompeii could have been supplied by the public water system (see for example Dessales 2008); considering that the water supply of Casa dell'Efebo and Casa dell'Orso was estimated in the range 0.45-0.80 1/s (Monteleone 2020), the simultaneous supply of the private residences could have demanded from 45 to $80 \mathrm{l} / \mathrm{s}$. The fact that this figure is close to the maximum supply of the aqueduct channel, possibly suggests the use of a timed supply, unless another aqueduct line was present.
} 
and flowrate valve; if this was the case their operation was not very efficient, being various water towers covered with thick deposits, formed by the water overflowing from the top tank.

\section{Conclusions}

In this study, a survey campaign was carried out in Pompeii archaeological site, gathering new data on the size of the spout orifices for 29 lacus fountains and on the size of the overflow channels for 31 lacus fountains.

A new method for estimating the water supplied to a lacus from the discharge of its overflow channels was introduced. This was done for the lowest, intermediate and highest assumed discharges. The size of the spout orifice for most of the fountains was recorded, enabling the size of the supply pipe to be deduced. By applying the calculated overflow discharges to the spout pipes, information on the flow velocity was derived. By calculating the water jet trajectory at the spout, it was possible to comment on what values of discharge might have been too high, so that they were excluded from the rest of the calculations.

A new parameter, the hydraulic retention time, relevant in the understanding of the quality of the water available in the lacus draw basins was introduced, with values for the Pompeian lacus lower than $3 \mathrm{~h}$.

Considerations on the total discharge needed to supply water to 39 lacus, calculated in $1 / \mathrm{s}$ and in quinariae, concluded that the castellum divisorium and the aqueduct channel discharging into it, could deliver the lowest and intermediate fountain discharges, but probably could not support the highest discharges. Indications on some variations in time, in the supply of some fountains, have been given.

The results presented in this study can be confirmed with the hydraulic analysis of the pipelines connecting the fountains to a nearby water tower; we hope to complete this other study and make it available soon.

Open Access This article is licensed under a Creative Commons Attribution 4.0 International License, which permits use, sharing, adaptation, distribution and reproduction in any medium or format, as long as you give appropriate credit to the original author(s) and the source, provide a link to the Creative Commons licence, and indicate if changes were made. The images or other third party material in this article are included in the article's Creative Commons licence, unless indicated otherwise in a credit line to the material. If material is not included in the article's Creative Commons licence and your intended use is not permitted by statutory regulation or exceeds the permitted use, you will need to obtain permission directly from the copyright holder. To view a copy of this licence, visit http://creativecommons.org/licenses/by/4.0/.

\section{References}

Agusta-Boularot S (1997) La fontaine, la ville et le Prince. Recherches sur les fontaines monumentales et leur fonction dans l'urbanisme impérial, de l'avènement d'Auguste au règne de Sévère Alexandre. Thèse de doctorat, Aix-Marseille 1

Agusta-Boularot S (2008a) Dare Aquas. Les enjeux politiques du "don de l'eau" dans les villes d'Italie républicaine. Histoire Urbaine 2:11-26

Agusta-Boularot S (2008b) Le lacus de la rue romaine: un exemple de 'mobilier urbain' antique? In Dieudonne' N, Saliou C (eds) La rue dans l'antiquité': définition, aménagement et devenir. Rennes, Presses Universitaires de Renne, pp 93-100

Brissaud PL (2004) Bassins et fontaines a Saint Roman en Gal. Dossiers d'Archeologie 295:9-109 
Bruun C (2003) Frontinus and the "Nachleben" of his De aquaeductu from Antiquity to the Baroque. In: Bruun C, Saastamoinen A (eds) Technology, ideology, water: from Frontinus to the Renaissance and beyond. Rome, Institutum Romanum Finlandiae, pp 41-80

Chadwick A, Morfett J, Borthwick M (2013) Hydraulics in civil and environmental engineering, 5th edn Boca Raton, CRC Press

Delaval E, Savay-Guerraz H (2004) Les fontaines de Lyon. Dossiers d'Archeologie 295:70-81

Dessales H (2008) Des usages de l'eau aux évaluations démographiques. L'exemple de Pompéi. Maison des Sciences de l'Homme Histoire urbaine 22:27-41

Dessales H (2011) L'eau en partage: les raccordements hydrauliques dans les maisons et structures artisanales (Herculanum, Pompéi). In: Fontaine S, Satre S, Tecchi A (eds) La ville au quotidien. Regards croisés sur l'habitat et l'artisanat antiques (Afrique du Nord, Gaule et Italie). Actes du colloque MMSH, 23-24 November 2007, Aix-en-Provence, Publication de 1'Université de Provence, pp $137-151$

Eschebach L (1996) Wasserwirtschaft in Pompeii. In: Cura aquarum in Campania. In: Proceedings of the Ninth International Congress on the History of Water Management and Hydraulic Engineering in the Mediterranean Region, Pompeii 1-8 October 1994, Babesch Suppplements 4, Leuven, Peeters Publishers, pp 1-12

Eschebach H, Schafer T (1983) Die öffentlichen Laufbrunnen Pompejis. Katalog und Beschreibung. Bollettino dell'Associazione Internazionale Amici di Pompei 1:11-39

Evans HB (1994) Water distribution in ancient Rome. The evidence of Frontinus. Ann Arbor, University of Michigan Press

Fahlbusch H (2006) Wasserwirtschaftliche Anlagen des antiken Priene. In: Wiplinger G (ed) Cura aquarum in Ephesus. Proceedings of the twelfth international congress on the history of water management and hydraulic engineering in the Mediterranean region. Ephesus, 2-10 October 2004, Bulletin antieke beschaving. Supplement 12, Leuven, Peeters Publishers, pp 117-126

Gerber F, Bambagioni F (2009) Le lacus des Hospitalières (Poitiers, Vienne) L'eau : usages, risques et représentations dans le sud-Ouest de la Gaule et le Nord de la péninsule ibérique (IIe siècle a.C.VIe siècle p.C), Actes du colloque international de la Fédération Aquitania. Dax, 25-26 September 2009, Aquitania, Supplément 21, pp 541-567

Hartnett J (2008) Fountains at Herculaneum: sacred history, topography and civic identity. Rivista di Studi Pompeiani XIX:77-89

Hodge AT (1996) Anomalies in flow at the Pompeii castellum. In: Proceedings of the ninth international congress on the history of water management and hydraulic engineering in the Mediterranean region, Pompeii 1-8 October 1994, Babesch Suppplements 4, Leuven, Peeters Publishers, pp 13-18

Jansen GCM (2002) Water in de Romeinse stad: Pompeji, Herculaneum, Ostia, Leuven, Peeters Publishers

Keenan-Jones D (2015) Somma-Vesuvian ground movements and the water supply of Pompeii and the bay of Naples. AJA 2:191-215

Kessener P (2013) Frontinus-Pompeii- Nîmes, English version of Kessener P., Gedanken über Frontin's quinaria. In: Frontinus Gesellschaft e.V. (2013) Die Wasserversorgungim im antiken Rom. Munchen, R. Oldenbourg, pp 175-188

Lanciani R (1880) Topografia di Roma antica. I commentarii di Frontino intorno le acque e gli acquedotti. Silloge epigrafica aquaria Reprinted in Memorie della Reale Accademia dei Lincei, Serie 3, 4 (1881), accessed as the reprint Le acque e gli acquedotti di Roma antica, Rome, Quasar (1975)

Lamare N (2019) Le fontaines monumentales en Afrique Romaine. Collection de l'École française de Rome, 557. Rome, École française de Rome

Loridant PF (2004) Les fontaines dans le nord. Dossiers d'Archeologie 295:36-45

Maiuri A (1973) Alla ricerca di Pompei preromana. Napoli, Societa editrice napoletana, pp 15-42

Matsui S, Sorrentino L, Sakai S, Shimizu Y, Iorio V (2009) La provenienza dell'acqua potabile nell'antica Pompei: un'ipotesi basata sull'analisi chimica dei residui calcarei degli impianti idrici. J Fasti Online. www.fastionline.org/docs/FOLDER-it-2009-162.pdf

Monteleone MC (2009) Fountains in the streets of Pompeii: the evaluation of the outlet velocity and of the expected flowrate from the features of fifteen fountains. In: Proceedings of the second IWA international symposium on water and wastewater technologies in ancient civilisation, Bari, 28-30 May 2009

Monteleone MC (2020) Le reti di distribuzione di acqua potabile in epoca romana. Fistule ritrovate e quantità di acqua erogata in due case Pompeiane. In: Proceedings of the 4th AISI international conference on the history of engineering. April 2020, Naples. Naples, Cuzzolin Editore, pp 173-188

Motta D, Keenan-Jones D, Garcia MH, Fouke BW (2017) Hydraulic evaluation of the design and operation of ancient Rome's Anio Novus aqueduct. Archaeometry 59(6):1150-1174 
Nappo SC (2002) L'impianto idrico a Pompei. I nuovi dati. In Binos Actus Lumina. Rivista di studi e ricerche sull'idraulica storica $\mathrm{I}: 91-108$

Nir-El Y (2017) Names and sizes of Roman lead pipes for water conduction. In: Wellbrock K (ed) Schriften der Deutschen Wasserhistorischen Gesellschaft, Band 27-2. Siegburg, pp 645-655

Nishida Y (1990) Measuring structures in Pompeii. Opusc Pompeiana 1:91-103

Ohlig CPJ (2001) De aquis Pompeiorum: das castellum aquae in Pompeii: Herkunft, Zuleitung und Verteilung des Wasser. Circumvesuviana 4, Norderstedt, Books on Demand GmbH

Ortoloff CR, Crouch DP (2001) The urban supply and distribution system of the Ionian city of Ephesos in the Roman imperial period. J Archaeol Sci 28(8):843-860

Pace P (1986) Gli acquedotti di Roma e il De aqueductu di Frontino. Rome, Art Studio S. Eligio

Poehler E (2017) The traffic systems of Pompeii. New York, Oxford University Press

Richard J (2016) Stagnant beauties? Some reflections on the speed of the water flow in Roman Nymphaea. In Wiplinger G (ed) De Aquaeductu atque Aqua Urbium Lyciae Pamphyliae Pisidiae. The Legacy of Sextus Julius Frontinus. Proceedings of the Frontinus international symposium. Antalya, 31. October-9. November 2014, Babesch Supplements 27, Peeters Publishing, pp 275-281

Richard J (2012) Water for the city, fountains for the people. Monumental fountains in the Roman east: an archaeological study of water management. Studies in Eastern Mediterranean Archaeology IX, Turnhout, Brepols Publisher

Rodgers RH (2004) Frontinus, De aquaeductu urbis Romae. Cambridge classical texts and commentaries 42. Cambridge, Cambridge University Press

Schmölder-Veit A (2009) Brunnen in den Städten des westlichen Römischen Reichs. Palilia 19. Wiesbaden, L.Reichert

Som SK, Biswas G (2008) Introduction to fluid mechanics and fluid machines. New Delhi, McGraw-Hill Education (India)

Stanco EA (2009) Bocche di fontana da Allifae e Telesia. Orizzonti X:121-129

Vannesse M, Haut B, Debaste F, Viviers D (2014) Analysis of three private hydraulic systems operated in Apamea during the Byzantine period. J Archaeol Sci 46:245-254

Wilson A (2007) The castra of Frontinus: Res bene gestae: ricerche di storia urbana su Roma antica in onore di Eva Margareta Steinby. Lexicon Topographicum Urbis Romae Supplementum IV:439-444

Publisher's Note Springer Nature remains neutral with regard to jurisdictional claims in published maps and institutional affiliations. 